\title{
Deficiency of the Thyroid Hormone Transporter Monocarboxylate Transporter 8 in Neural Progenitors Impairs Cellular Processes Crucial for Early Corticogenesis
}

\author{
Pieter Vancamp, ${ }^{-M a r i e-A n n e ~ D e p r e z, ~ M i c h i e l ~ R e m m e r i e, ~ a n d ~ V e e r l e ~ M . ~ D a r r a s ~}$ \\ Laboratory of Comparative Endocrinology, Department of Biology, KU Leuven, B-3000 Leuven, Belgium
}

Thyroid hormones (THs) are essential for establishing layered brain structures, a process called corticogenesis, by acting on transcriptional activity of numerous genes. In humans, deficiency of the monocarboxylate transporter 8 (MCT8), involved in cellular uptake of THs before their action, results in severe neurological abnormalities, known as the Allan-Herndon-Dudley syndrome. While the brain lesions predominantly originate prenatally, it remains unclear how and when exactly MCT8 dysfunction affects cellular processes crucial for corticogenesis. We investigated this by inducing in vivo RNAi vector-based knockdown of MCT8 in neural progenitors of the chicken optic tectum, a layered structure that shares many developmental features with the mammalian cerebral cortex. MCT8 knockdown resulted in cellular hypoplasia and a thinner optic tectum. This could be traced back to disrupted cell-cycle kinetics and a premature shift to asymmetric cell divisions impairing progenitor cell pool expansion. Birth-dating experiments confirmed diminished neurogenesis in the MCT8-deficient cell population as well as aberrant migration of both early-born and late-born neuroblasts, which could be linked to reduced reelin signaling and disorganized radial glial cell fibers. Impaired neurogenesis resulted in a reduced number of glutamatergic and GABAergic neurons, but the latter additionally showed decreased differentiation. Moreover, an accompanying reduction in untransfected GABAergic neurons suggests hampered intercellular communication. These results indicate that MCT8-dependent TH uptake in the neural progenitors is essential for early events in corticogenesis, and help to understand the origin of the problems in cortical development and function in Allan-Herndon-Dudley syndrome patients.

Key words: chicken; corticogenesis; MCT8; optic tectum; thyroid hormone

Significance Statement

Thyroid hormones (THs) are essential to establish the stereotypical layered structure of the human forebrain during embryonic development. Before their action on gene expression, THs require cellular uptake, a process facilitated by the TH transporter monocarboxylate transporter 8 (MCT8). We investigated how and when dysfunctional MCT8 can induce brain lesions associated with the Allan-Herndon-Dudley syndrome, characterized by psychomotor retardation. We used the layered chicken optic tectum to model cortical development, and induced MCT8 deficiency in neural progenitors. Impaired cell proliferation, migration, and differentiation resulted in an underdeveloped optic tectum and a severe reduction in nerve cells. Our data underline the need for MCT8-dependent TH uptake in neural progenitors and stress the importance of local TH action in early development.

\section{Introduction}

The development of the cerebral cortex (i.e., corticogenesis) is a complex process that includes proliferation of neural progenitors, radial and tangential cell migration, and the structural orga-

\footnotetext{
Received July 10, 2017; revised 0ct. 2, 2017; accepted 0ct. 19, 2017.

Author contributions: P.V. and V.M.D. designed research; P.V., M.-A.D., and M.R. performed research; P.V., M.-A.D., and M.R. analyzed data; P.V. and V.M.D. wrote the paper.

This work was supported by grants from the Research Foundation Flanders and the Research Council of the KU Leuven. The authors thank Lut Noterdaeme for technical assistance, Margarita Pitsiani and Prof. R. Wingate for the pTRE-AP reporter construct, Prof. A. Goffinet for the reelin antibody, Prof. E. Seuntjens for suggestions regarding the content, Prof. Tom Wenseleers for statistical advice, and Karel Haesevoets for providing the graphical sketch.

The authors declare no competing financial interests.
}

nization of cells into layers. Subsequent cell differentiation and synaptogenesis establish the basic cortical circuit necessary for efficient processing of sensory information (Molnar et al., 2006). Thyroid hormones (THs) are known to be important mediators of mammalian corticogenesis from early stages of development onwards (Berbel et al., 2014; Moog et al., 2017). Induction of hypothyroidism during fetal corticogenesis in rodents consequently results in multiple impairments, such as disrupted cell-

Correspondence should be addressed to Prof. Veerle M. Darras, Laboratory of Comparative Endocrinology, Naamsestraat 61, P.0. Box 2464, B-3000 Leuven, Belgium. E-mail: veerle.darras@bio.kuleuven.be.

DOI:10.1523/JNEUROSCI.1917-17.2017

Copyright $\odot 2017$ the authors $\quad 0270-6474 / 17 / 3711616-16 \$ 15.00 / 0$ 
cycle kinetics, impaired neuronal migration, and reduced cortical thickness (Ausó et al., 2004; Mohan et al., 2012).

$\mathrm{TH}$ nuclear receptor-mediated signaling is highly heterogeneous among developing cortical regions, affecting different subsets of genes, depending on time and place of TH action (Chatonnet et al., 2015; Bernal, 2017). Transmembrane transporters facilitating TH uptake and efflux together with $\mathrm{TH}$-(in)activating enzymes called deiodinases strictly determine the local availability of the biologically active 3,5,3'-triiodothyronine $\left(\mathrm{T}_{3}\right.$; Mendoza and Hollenberg, 2017). The most specific TH transporter identified in different vertebrates so far is the monocarboxylate transporter 8 (MCT8; Friesema et al., 2003; Arjona et al., 2011; Bourgeois et al., 2016; Mughal et al., 2017). Inactivating mutations in the human SCL16A2 gene coding for MCT8 result in an $\mathrm{X}$-linked syndrome of severe psychomotor retardation called the Allan-Herndon-Dudley syndrome (AHDS; Friesema et al., 2004; Schwartz et al., 2005). Impaired neuronal differentiation, reduced cortical thickness, delayed cerebral development, and poor myelination are among the severe manifestations of AHDS (Dumitrescu et al., 2013; López-Espíndola et al., 2014). However, the neurological outcome associated with MCT8 deficiency is considerably different from that of cretinism, which originates from a general shortage of active TH (Kurian and Jungbluth, 2014; López-Espíndola et al., 2014). This suggests TH deficiency differentially affects brain development, depending on time and place of action. So far, the need of MCT8-dependent TH uptake has been demonstrated at the level of the blood-brain barrier in perinatal and postnatal stages in rodents (Roberts et al., 2008; Ceballos et al., 2009; Vatine et al., 2017), and more recently also in neural circuit assembly in zebrafish (Zada et al., 2014), and in differentiating Purkinje cells of the chicken cerebellum (Delbaere et al., 2017). However, unaddressed yet is whether MCT8 plays a role at the level of neural progenitors during corticogenesis. In addition, there is still no direct in vivo proof of MCT8 deficiency causing altered TH activity in neural progenitors.

To study the involvement of MCT8 in early corticogenesis in more detail, we chose the chicken optic tectum $(\mathrm{TeO})$, a mesencephalic structure that shares many features with the mammalian cerebral cortex (Nomura et al., 2009). This avian homolog of the mammalian superior colliculus develops in a similar fashion following a sequence of overlapping phases. First, the neuroepithelium undergoes massive cell proliferation to expand the progenitor cell population. Gradually, neuroblasts that have exited the cell cycle migrate radially to form the tectal layers. Early-born cells populate the deeper layers while later-born cells progressively form more superficial layers so that the cortex is established following an inside-out gradient with one exception: the latestborn neurons form the middle layers. Cell differentiation takes place during and after migration and determines the basic cytoarchitecture of the $\mathrm{TeO}$ (LaVail and Cowan, 1971; Lever et al., 2014). The mature $\mathrm{TeO}$ presents itself as 15 alternating neuronal and plexiform layers that receive visual input in a topographical manner (Mey and Thanos, 2000; Wylie et al., 2009). MCT8 is expressed throughout all phases of tectal development (Geysens et al., 2012), supporting the concept that TH uptake is necessary for proper TH action. The objective of this study was to investigate whether MCT8 expression in neural progenitors contributes to early corticogenesis and to gain insight on how and when MCT8 deficiency could account for lesions in the developing cortex of AHDS patients.

\section{Materials and Methods}

Chicken embryos. Fertilized eggs (Gallus gallus, white leghorn) were obtained from a commercial hatchery (Wyverckens), and were incubated in a forced draft incubator $\left(38^{\circ} \mathrm{C}, 55 \%\right.$ humidity) until the desired developmental stage was reached. Chicken embryonic development takes $21 \mathrm{~d}$ with the start of incubation defined as embryonic day 0 (E0). Embryos were sampled at specific developmental stages, regardless of sex. All experiments were conducted according to the European Directive 2010/63/ $\mathrm{EU}$, and were approved by the Ethical Committee of the KU Leuven (P005-2016).

Injection and electroporation. A window was cut in the egg at E3, making the chicken embryo accessible for experimental manipulation. The third brain ventricle was completely filled with the pRFP-RNAi vector (empty control vector; Das et al., 2006) or the pRFP-MCT8-RNAi vector $( \pm 2.5 \mu \mathrm{g} / \mu \mathrm{l})$ using a microinjector (Femtojet, Eppendorf). The construction of the pRFP-MCT8-RNAi vector was described previously (Delbaere et al., 2017). Cells transfected with the pRFP-RNAi vector or pRFP-MCT8-RNAi vector are visible by red fluorescent protein (RFP) expression. The injection solution also contained $0.1 \%$ Fast Green (Sigma-Aldrich) for visualization. The vectors were subsequently electroporated (settings: $12 \mathrm{~V}, 5$ square pulses of $50 \mathrm{~ms}$ ) into the left mesencephalic hemisphere with a $7 \mathrm{~mm}$ Tweezertrode (Harvard Apparatus) connected to a ECM 830 Electro Square Porator (BTX, Harvard Apparatus). Eggs were then resealed with tape and further incubated until sampling at different stages: E4, E6, E8, and E12.

Tissue sampling. Embryonic heads were collected for all stages $\leq \mathrm{E} 6$ while the brain was dissected for all stages $\geq E 8$. They were fixated overnight in $4 \%$ paraformaldehyde (PFA) in $1 \times$ PBS, followed by overnight incubation in $20 \%$ sucrose in $1 \times$ PBS, both at $4^{\circ} \mathrm{C}$. Tissue samples were then embedded in Tissue-Tek O.C.T. Compound (Sakura Finetek) by placing them on a metal stub in liquid nitrogen, after which samples could be stored at $-80^{\circ} \mathrm{C}$ until $12 \mu \mathrm{m}$ coronal cryosections were made.

Five-ethynyl-2'-deoxyuridine assays. To visualize S-phase cells at E4, embryos received an intravenous injection of $1 \mu \mathrm{l}$ 5-ethynyl-2'-deoxyuridine (EdU; $10 \mathrm{~mm}$ in $0.9 \% \mathrm{NaCl}) 1 \mathrm{~h}$ before sampling. Sampling was performed as described above, and sections were stained as recommended by the manufacturer (Thermo Fisher Scientific): postfixation with $4 \%$ PFA in $1 \times$ PBS, permeabilization in $0.1 \%$ Triton X-100 in $1 \times$ PBS, and blocking with $3 \%$ BSA in $1 \times$ PBS before 30 min incubation with the reaction mixture (reaction buffer, $\mathrm{CuSO}_{4}$, buffer additive, and Alexa 488 Fluor azide). DAPI (1:1000 in $1 \times$ PBS) was used as a background nuclear staining.

Birth-dating experiments were performed by dripping a single dose of $250 \mu \mathrm{l} \mathrm{EdU}$ solution $(500 \mu \mathrm{M}$ in $0.9 \% \mathrm{NaCl})$ on the embryo at $\mathrm{E} 4$ or E6. Embryos were then resealed and incubated until the brains were sampled at E8 and E12, after which the EdU staining was performed as described above.

TH-signaling assay. For the TH-signaling assay, a reporter construct was used containing a coding sequence for alkaline phosphatase (AP) under the control of an upstream TH response element (TRE). This reporter construct (pTRE-AP) was modified from a previously used retinoic acid reporter construct (pRARE-AP; Gupta and Sen, 2015), by replacing the retinoic acid response element (RARE) by a TRE (sequence with TH receptor binding sites in bold: CGACTTATTGAGGTCACTTC AGGTCACCAGAGATCTCTTCAGGTCACTTCAGGTCACAAGCTT CCTCGAGA), and was checked by sequencing [modification by Margarita Pitsiani and Professor R. Wingate (Kings College London, UK)]. The pRFP-RNAi or pRFP-MCT8-RNAi vector $( \pm 2.5 \mu \mathrm{g} / \mu \mathrm{l})$ was electroporated in combination with the pTRE-AP $( \pm 5 \mu \mathrm{g} / \mu \mathrm{l})$ in the left mesencephalic hemisphere at E3, after which samples were taken at E6 as described above. Cryosections were first washed in $1 \times$ PBS and Tris$\mathrm{NaCl}$-Tween 20 buffer. The presence of AP was then visualized by adding the substrate naphtol-AS-MX-phosphate $(50 \mathrm{mg} / \mathrm{ml}, 1: 500$; SigmaAldrich) and Fast Blue [50 mg/ml, 1:250 in staining buffer (Tris- $\mathrm{HCl}, \mathrm{pH}$ 8.2, $\mathrm{MgCl}_{2}, 5 \mathrm{M} \mathrm{NaCl}, 0.1 \%$ Tween20); Sigma-Aldrich) for $8 \mathrm{~h}$, resulting in the formation of a green light-emitting precipitate. Pictures were made using an FV-1000 confocal microscope (Olympus).

Western blot. E12 brains were dissected on ice and collected in $1 \times$ PBS. In case of extensive transfection and normal morphology, the medio- 
lateral part of the TeO transfected with the pRFP-RNAi or pRFPMCT8-RNAi vector was dissected on ice. Tissues were homogenized by sonication on ice (six pulses of $10 \mathrm{~s})$ in lysis buffer $(100 \mu \mathrm{l}$ of $65 \mathrm{~mm}$ Tris buffer, $\mathrm{pH} 8.0$, containing $2 \%$ SDS) combined with protease inhibitors (Roche). Samples were then heated for $5 \mathrm{~min}$ at $70^{\circ} \mathrm{C}$, and centrifuged at $13,000 \mathrm{rpm}$ for $15 \mathrm{~min}$ at $4^{\circ} \mathrm{C}$, where after the supernatant was transferred to a new tube and stored at $-80^{\circ} \mathrm{C}$ until further use. Protein concentration was measured by the Bradford method using protein assay dye reagent concentrate (Bio-Rad). Five micrograms of homogenized protein were loaded on a $4-12 \%$ SDS-polyacrylamide gel and transferred to a nitrocellulose membrane following electrophoresis. This membrane was blocked for $2 \mathrm{~h}$ in $5 \%$ milk powder (Nestlé) in $1 \times \mathrm{TBS}$, before overnight incubation with a custom-made rabbit anti-chicken MCT8 antibody (1:5000; Eurogentec). The membrane was then incubated with a HRPlabeled secondary antibody (1:20,000; Dako) and positive signal was visualized using a luminol-based enhanced chemiluminescent kit (Thermo Fisher Scientific) visible under an imaging system (Bio-Rad, ChemiDoc MP imaging system). The total amount of protein was semiquantified using the SWIFT method (G-biosciences).

Immunohistochemistry. Cryosections were permeabilized with $0.1 \%$ Triton X-100 in $1 \times$ PBS and blocked for $1 \mathrm{~h}$ with preimmune serum before adding the primary antibody overnight. The primary antibodies include a polyclonal rabbit anti-phosphohistone 3 (Ser10) antibody (anti-PH3, 1:400; Cell Signaling Technology, RRID:AB_9701S), a polyclonal mouse anti-reelin antibody (1:200; gift from Professor A. Goffinet, University of Louvain, Brussels, Belgium, RRID:AB_142), a monoclonal mouse anti-brain-specific homeobox/POU domain protein 3a antibody (anti-BRN3a, 1:100; Millipore, RRID:AB_1585), a monoclonal mouse anti-vimentin antibody (antibody H5, 1:200; Developmental Studies Hybridoma Bank, RRID:AB_528506), and a monoclonal mouse anti-LIM homeobox protein 1/5 antibody (anti-LHX1/5; antibody 4F2, 1:500; Developmental Studies Hybridoma Bank, RRID:AB_531784). Binding of primary antibodies was visualized using an Alexa 488-labeled secondary antibody (for BRN3a), or the TSA FT amplification kit (PerkinElmer; for $\mathrm{PH} 3$, Reelin, H5, and 4F2). Pictures were made with a FV-1000 confocal microscope (Olympus).

Experimental design and statistical analysis. Only sections through the mediolateral $\mathrm{TeO}$ were used for analysis to avoid bias due to the rostrocaudal and dorsoventral developmental gradient. Furthermore, to reduce the risk of bias in cell counts, they were always conducted on $\geq 2$ sections per animal (technical replicates) and were performed independently and blind for condition by two researchers. Further details regarding the cell counts are provided in the Results section for each experiment. The image processing software FIJI was used for all cell counts (Schindelin et al., 2012). The value of $n$ represents the number of animals used (biological replicates) per condition. The obtained values are shown as scatter plots depicting mean $\pm \mathrm{SD}$ or as horizontal bars/squares showing mean $\pm \mathrm{SD}$.

All statistical tests were performed using Prism version 7.00 for Windows (GraphPad Software, www.graphpad.com). Before analysis, normal distribution of the data was checked by the Kolmogorov-Smirnov test and size of the variance between groups was checked via the $F$ test for equality of two variances. When one of these preconditions was not met, a nonparametrical test was used instead. To evaluate MCT8 knockdown, an unpaired one-tailed Student's $t$ test was performed, where the degrees of freedom (Df) are defined as $n_{1}+n_{2}-1$. All other comparisons of one variable between two groups (i.e., one independent variable) was done via an unpaired, two-tailed Student's $t$ test with $D f=n_{1}+n_{2}-2$ or, in case of no normal distribution, a Mann-Whitney $U$ test. In case of two independent variables, results were analyzed via two-way ANOVA. $F$ values are provided together with $D f_{1}=k-1$, with $k$ the number of treatments, and $D f_{2}=n-k$. In case of a significant outcome, the ANOVA was followed by a Sidak post hoc test to detect which conditions differed from one another, and the associated $t$ values are shown together with $D f=n-k$. Results were considered significant when $p<0.05\left(^{*}\right)$, $\left.p<0.01{ }^{* *}\right)$, and $p<0.001\left(^{* * *}\right)$, and exact values are provided in Results unless $p<0.0001$.

\section{Results \\ pRFP-MCT8-RNAi transfection results in reduced MCT8 expression and TH signaling.}

Unidirectional electroporation of the pRFP-RNAi (empty control vector) or pRFP-MCT8-RNAi vector into the mesencephalon at E3 (Fig. 1A) resulted in the transfection of the left mesencephalic hemisphere (i.e., the left optic lobe), as visualized by RFP expression (Fig. 1B). To confirm knockdown of MCT8 protein during the entire time frame of interest (E3-E12), we performed Western blot analysis of E12 samples of the mediolateral part of the transfected optic lobe for both conditions. Two bands are visible: one corresponding to the molecular weight of the MCT8 monomer $(55.15 \mathrm{kDa})$ and a band with a higher molecular weight, possibly corresponding to a dimer. Signal intensity was visibly lower in protein lysates of the pRFP-MCT8-RNAi-transfected $\mathrm{TeO}$ (Fig. 1C). Semiquantitative analysis of the monomer band via SWIFT revealed a reduction of $\sim 50 \%$ of MCT 8 protein at E12 $\left(n=5\right.$, one-tailed $t$ test, $\left.t_{(9)}=2.342, p=0.0219\right)$. As only part of the cells in the lysates are transfected $(<50 \%)$, this indicates a sustained and strong depletion of MCT8 in the pRFP-MCT8RNAi-transfected cells. We also electroporated a reporter construct (pTRE-AP), in combination with either the pRFP-RNAi or the pRFP-MCT8-RNAi vector, to visualize TH signaling at the transfection sites. Signal intensity was studied in strongly transfected regions of the $\mathrm{TeO}$ of seven animals per condition. Cells transfected with the pRFP-RNAi vector clearly show a green signal, confirming the presence of TH signaling at E6, as shown here in representative pictures of three different animals (Fig. 1D). Transfection with the pRFP-MCT8-RNAi vector resulted in a strongly reduced green signal in almost all transfected cells (Fig. $1 E)$, validating the specific effect of our knockdown strategy.

\section{MCT8 knockdown results in a hypoplastic $\mathrm{TeO}$}

The development of the $\mathrm{TeO}$ is typically accompanied by a strong increase in tectal thickness starting at the moment of neurogenesis. The TeO thickness was reduced by $\sim 140 \mu \mathrm{m}$ at E12 following pRFP-MCT8-RNAi transfection at E3, which is a $13 \%$ loss of total thickness (data not shown; $n=12$, two-tailed $t$ test, $t_{(22)}=$ $3.394, p=0.0026)$. As almost all cells have been generated and the formation of the TeO layers is completed at E12 (Mey and Thanos, 2000), we further explored the cellular buildup. Coronal sections through the mediolateral TeO (Fig. 2A) show that cells transfected with the pRFP-RNAi vector are spread across all tectal layers (Fig. 2B). In contrast, the TeO transfected with the pRFPMCT8-RNAi vector shows reduced spreading of the RFP-positive cells, as the signal is almost exclusively found in the inner tectal layers (Fig. 2C). Apparently, pRFP-MCT8-RNAi-transfected cells fail to reach the outer tectal layers and remain localized close to the ventricular zone where they were born.

More detailed analysis of tectal cell numbers was done by dividing the $\mathrm{TeO}$ into five horizontal sections based on McGowan et al. (2012; Fig. 2B, right). The inner layers are generated first and, starting at the bottom, comprise the stratum fibrosum periventriculare (SFP), stratum griseum periventriculare (SGP), stratum albumen centrale (SAC), and stratum griseum centrale (SGC). Next, the stratum griseum et fibrosum superficiale (SGFS) a-g or outer layers are generated and divided in the SGFS a-f and the densely packed SGFS g. Finally, the SGFS $h$ and SGFS i represent the middle layers and are generated last. A region of interest (ROI; a rectangle $100 \mu \mathrm{m}$ wide and the height of the $\mathrm{TeO}$ ) was selected in the mediolateral $\mathrm{TeO}$ to perform cell counting. The ventricular zone was systematically left out for counting as this layer forms the ependymal layer at E12 and is not part of the functional TeO 
A

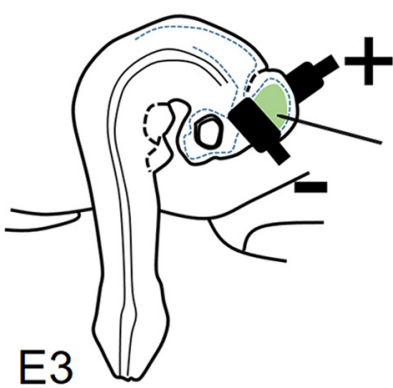

B

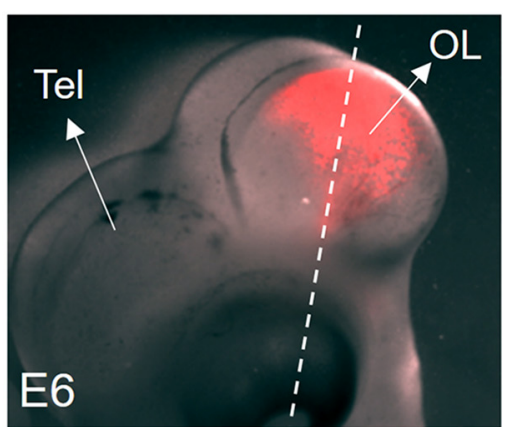

C

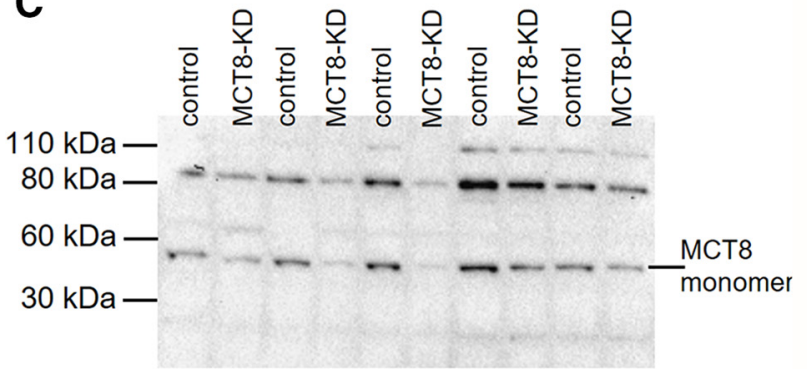

D

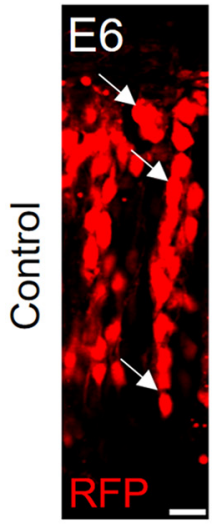

Embryo 1

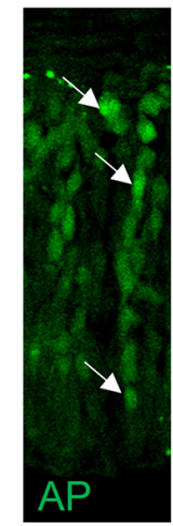

E

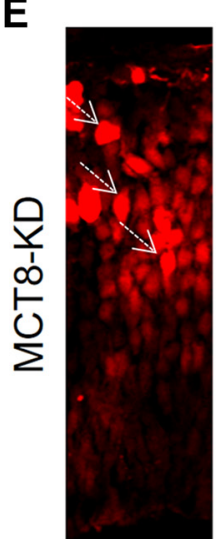

Embryo 2
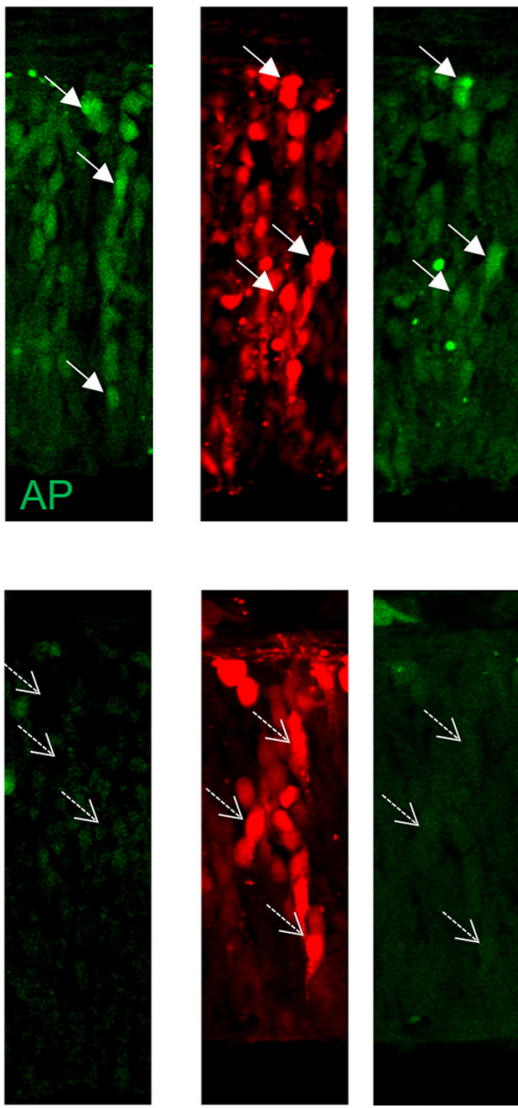

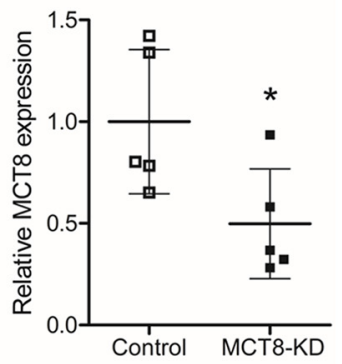

Embryo 3
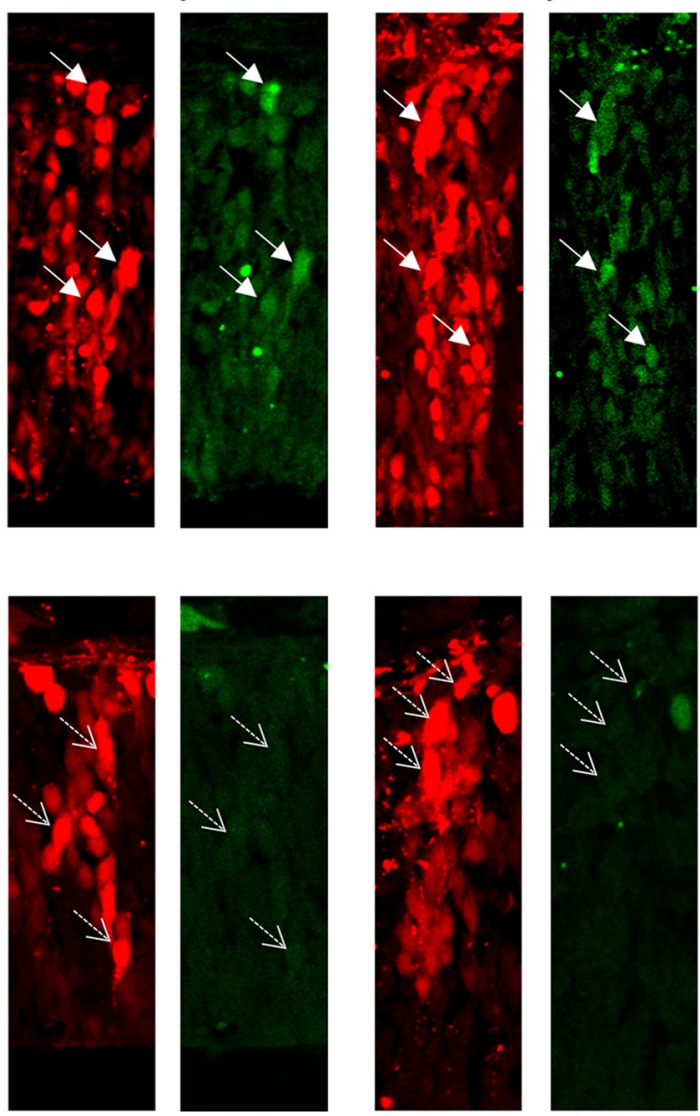
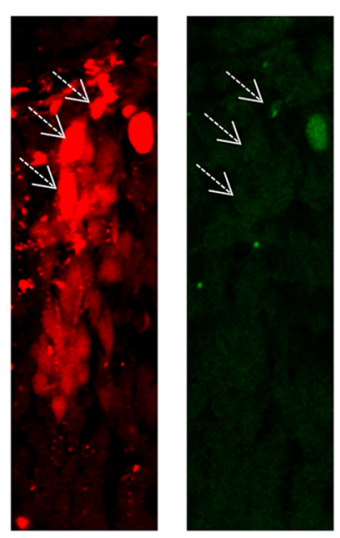

Figure 1. PRFP-MCT8-RNAi transfection results in reduced MCT8 protein expression and TH signaling. $\boldsymbol{A}$, Injection of the green solution containing the pRFP-RNAi or pRFP-MCT8-RNAi vector into the third ventricle, and subsequent electroporation at E3 using a Tweezertrode with the positively charged electrode placed under the left mesencephalon. $\boldsymbol{B}$, Successful transfection of the left optic lobe visualized by extensive RFP expression at E6. For analyzing TH signaling $(\boldsymbol{D}, \boldsymbol{E})$ coronal sections were made through the embryonic head (white dotted line). C, Western blot showing pRFP-MCT8-RNAi transfection results in a partial downregulation of MCT8 protein levels in the mediolateral optic lobe at E12 (containing transfected as well as untransfected cells). A scatter plot (including mean \pm SD) of the relative signal intensity in the MCT8 monomer band shows an average loss of $50 \%$ of protein expression. $\boldsymbol{D}$, Representative pictures of transfection sites in the E6 Te0 of three different embryos, showing most cells transfected with the pRFP-RNAi vector (red) overlap with green signal (white arrows), an indication of TH signaling. The green signal is the

itself. Likewise, the stratum opticum (SO) containing retinal axon fibers was not included.

The total number of DAPI-positive cells in the ROI at E12 is 16\% lower in the MCT8-knockdown condition compared with controls ( $n=8-9$, two-tailed $t$ test, $\left.t_{(15)}=3.052, p=0.0081\right)$. When only counting transfected RFP-positive cells, the number is decreased by $\sim 80 \%$ in the MCT8-knockdown condition $(n=8-9$, two-tailed $t$ test, $t_{(15)}=14.56, p<0.0001$; Fig. 2D). The loss of RFP-positive cells actually equals the loss of DAPI-positive cells of the total cell population, indicating that the cell number in the untransfected population was unaffected. The total cell loss is most apparent in the inner layers $(n=8-9$, Sidak post hoc test following two-way ANOVA, $t_{(15)}=3.404, p=$ 0.00533 ), while the number of transfected cells is significantly lower in all cell layers of the MCT8-knockdown condition $(n=$ 8-9, two-way ANOVA, $F_{(1,15)}=212.1$, $p<0.0001$; Fig. $2 E$ ). Only the inner layers contain a substantial number of RFP-positive cells, although still significantly fewer than in the control condition. This indicates that the few pRFP-MCT8-RNAi-transfected cells formed only occasionally reached the outer tectal layers. As a consequence, these cells are not arranged in layers as noticeable for the untransfected DAPI-positive cells (Fig. 2C). Overall, these data show that MCT8 knockdown results in a thinner, hypoplastic $\mathrm{TeO}$ at E12.

MCT8 knockdown disrupts cell-cycle kinetics and obstructs progenitor cell pool expansion.

To further explore the underlying nature of the hypoplasia, we investigated cell proliferation at E4 and E5, the phases of maximal progenitor cell pool expansion in the $\mathrm{TeO}$ (Mey and Thanos, 2000). In this phase, the neuroepithelium consists of neural progenitors in various phases of the cell cycle present at characteristic locations. Cells in the phase of DNA synthesis (i.e., $\mathrm{S}$ phase) were labeled with EdU administered $1 \mathrm{~h}$ before sampling. RFPpositive cells are distributed across the entire radial gradient of the tectal neuro-

\section{$\leftarrow$}

result of the formation of a green light-emitting precipitate by the AP expressed from the pTRE-AP. Scale bar, $20 \mu \mathrm{m}$. Most cells transfected with the pRFP-MCT8-RNAi vector show a strong reduction or even complete absence of green signal (white dotted arrows). AP, Alkaline phosphatase; Control, PRFP-RNAi transfection; MCT8-KD (knockdown condition), pRFP-MCT8-RNAi transfection; OL, optic lobe; Tel, telencephalon. ${ }^{*} p<0.05$. 
A

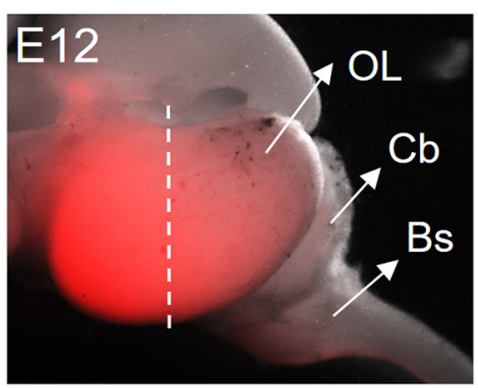

B
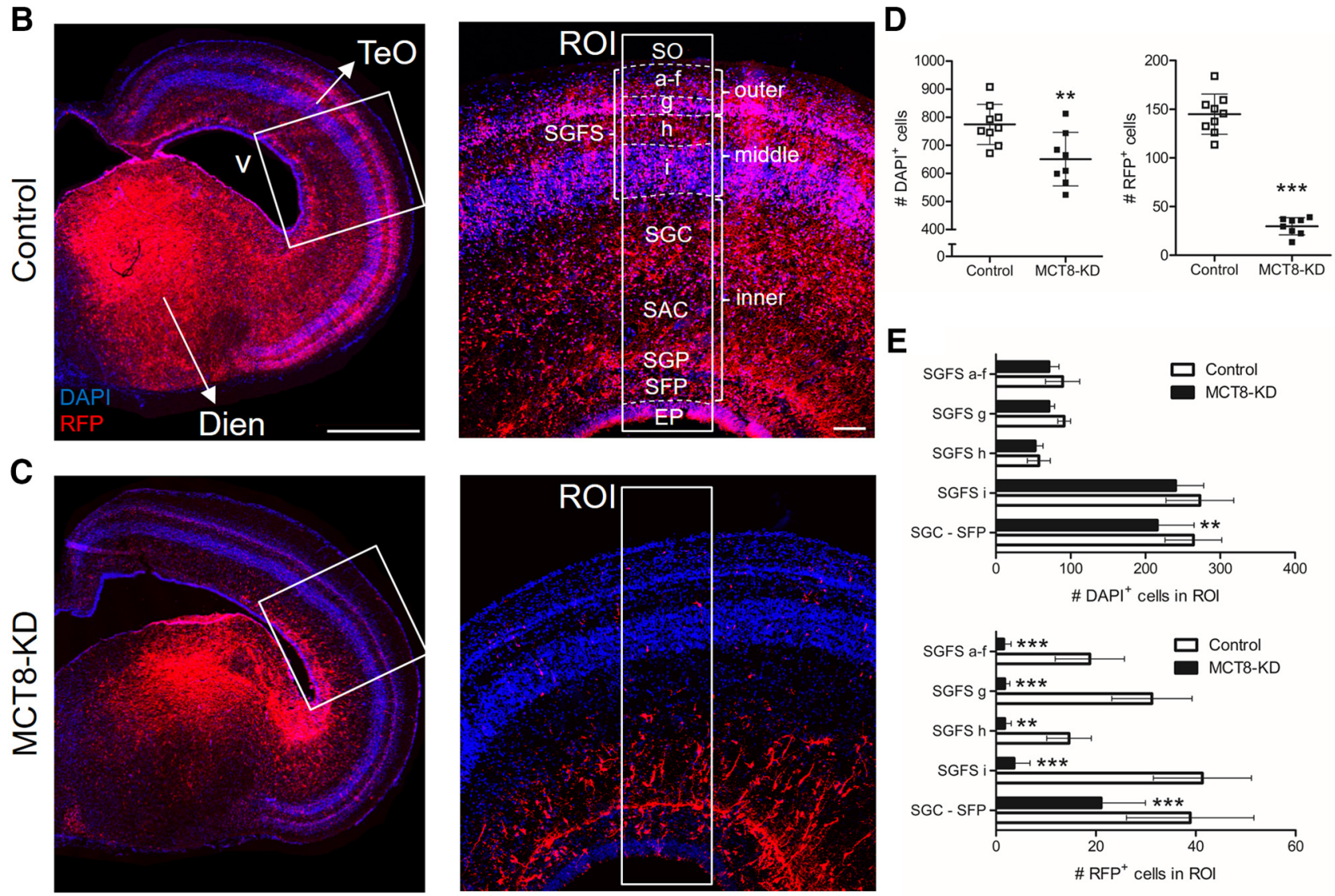

Figure 2. MCT8 knockdown results in a hypoplastic Te0. $A$, Side view of the caudal brain at E12 showing successful transfection of the left optic lobe visualized by extensive RFP expression. All analyses were performed on coronal sections through the optic lobes in the middle region along the rostrocaudal axis (white dotted line). $\boldsymbol{B}$, Strong RFP expression is observed throughout the Te0 as well as the diencephalon in the control condition. A detailed picture of the white box in the left panel shows the layered structure of the Te 0 and the applied nomenclature. An ROI was consistently selected (right, white box) to perform cell counting. Scale bars: left, $1 \mathrm{~mm}$; right, $100 \mu \mathrm{m}$. C, RFP expression is predominantly present in the inner region of the Te0 in the MCT8-knockdown condition. A detailed picture of the white box in the left panel reveals the nearly complete absence of pRFP-MCT8-RNAi-transfected cells in the outer layers. Cell counting was performed in an ROI similar to the controls. D, Scatter plots (including mean \pm SD) showing the total number of cells $\left(\mathrm{DAPI}^{+}\right.$) and the number of transfected cells $\left(\mathrm{RFP}^{+}\right)$in the ROl is reduced following pRFP-MCT8-RNAitransfection. $\boldsymbol{E}$, Bar graphs (mean $\pm \mathrm{SD}$ ) showing the number of DAPI ${ }^{+}$cells is only reduced in the inner layers, while the number of RFP ${ }^{+}$cells is strongly reduced in all layers. Control, pRFP-RNAi transfection; MCT8-KD (knockdown condition), PRFP-MCT8-RNAi transfection; Bs, brainstem; Cb, cerebellum; Dien, diencephalon; EP, ependymal layer; OL, optic lobe; SAC, stratum albumen centrale; SFP, stratum fibrosum periventriculare; $\mathrm{SGC}$, stratum griseum centrale; $\mathrm{SGFS}$, stratum griseum et fibrosum superficiale; $\mathrm{SGP}$, stratum griseum periventriculare; $\mathrm{SO}$, stratum opticum; $\mathrm{v}$, ventricle. ${ }^{* *} p<$ $0.01,{ }^{* * *} p<0.001$.

epithelium. In the control condition, the EdU-positive cells are almost exclusively located in the subventricular zone, as expected, and a vast number of RFP-positive cells are EdU-positive (Fig. $3 \mathrm{~A}$, yellow cells). While EdU-positive cells are also present in the pRFP-MCT8-RNAi-transfected neuroepithelium, regions with RFP-positive cells contain only few EdU-positive cells, visible as a reduced number of yellow cells. Moreover, EdU-positive cells are also present in the ventricular zone, where S-phase cells normally do not reside (Fig. 3B), which indicates a reduced S-phase length in pRFP-MCT8-RNAi-transfected progenitor cells (Mohan et al., 2012). Surprisingly, most of these heterotopic cells are untrans- fected. Normally cells leaving the $S$ phase then migrate to the ventricular zone and start the mitotic phase (i.e., $M$ phase), visualized by staining for PH3. M-phase cells in the tectal neuroepithelium appear at the ventricular border at $\mathrm{E} 4$ in both conditions, but are less abundant in the MCT8-knockdown condition (Fig. $3 C, D)$.

To quantify these observations, we counted $\geq 30$ RFP-positive cells on $\geq 2$ detailed images of the $\mathrm{TeO}$ per animal, and determined which of these cells expressed the marker EdU or PH3. Statistical analysis of the fraction of EdU-positive cells in the RFP-positive population reveals a strong reduction of almost 
A

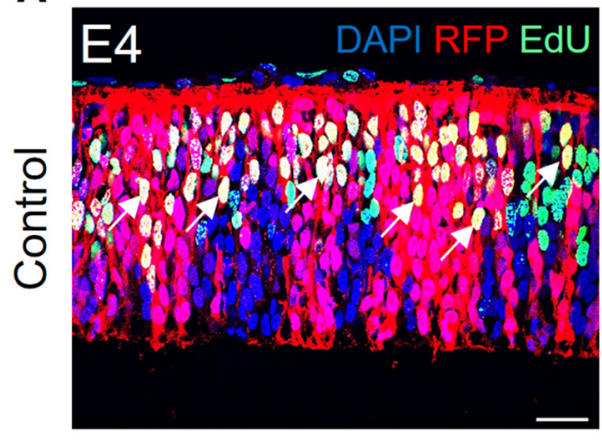

B

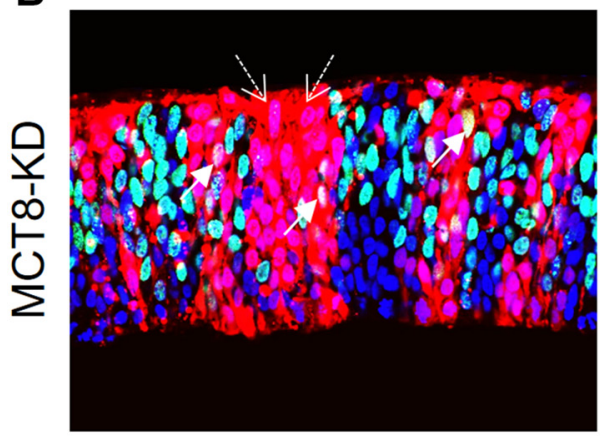

C

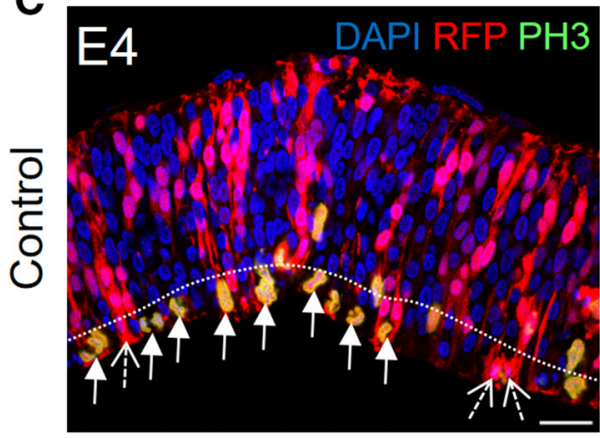

D

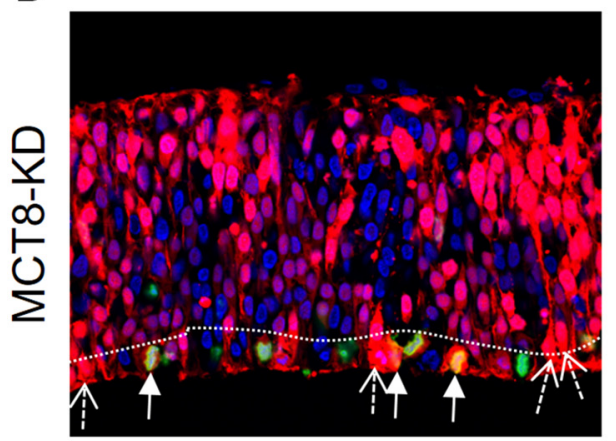

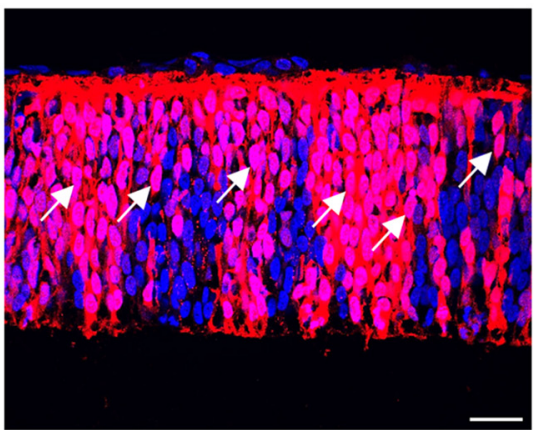
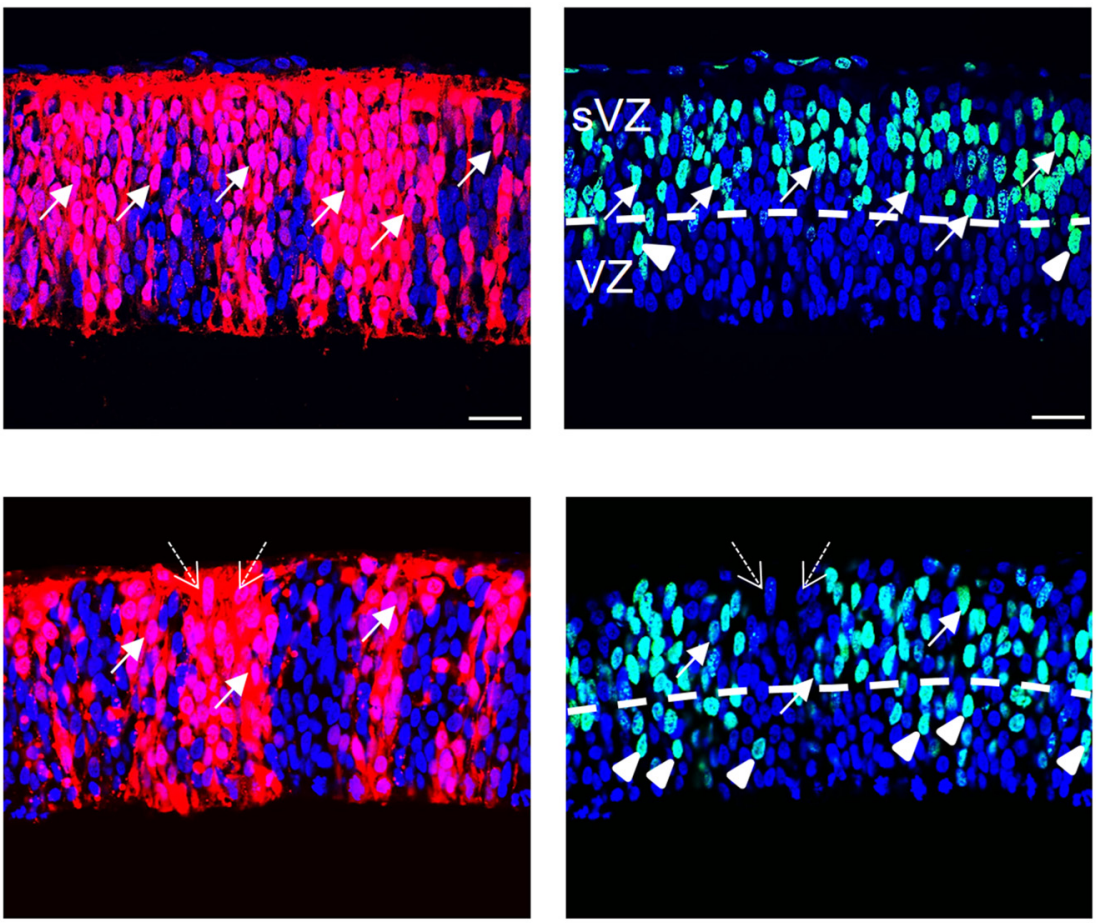

E
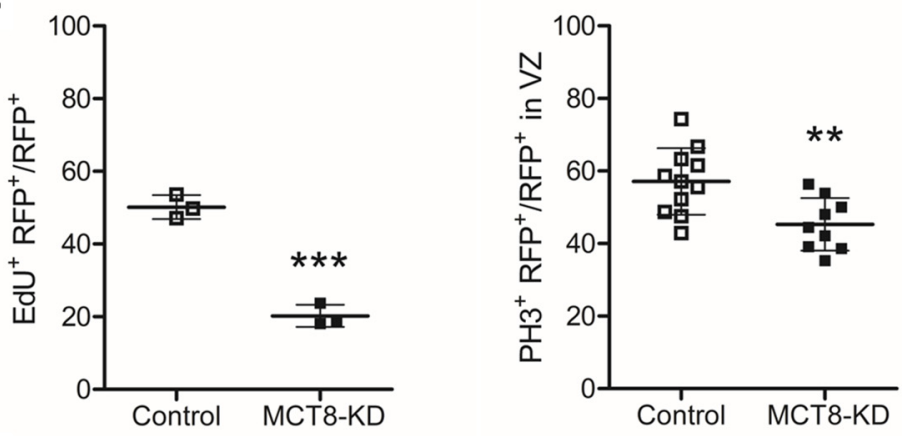

F
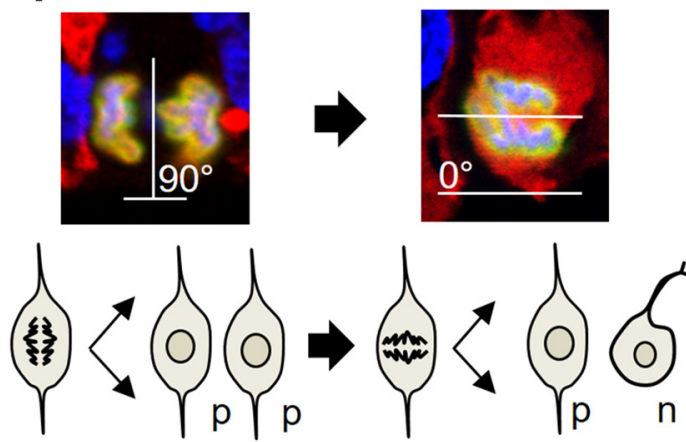

Figure 3. MCT8 knockdown disrupts cell-cycle kinetics and obstructs progenitor cell pool expansion. $\boldsymbol{A}$, Coronal section through the tectal neuroepithelium at E4 showing EdU ${ }^{+}$(green) and cells transfected with the pRFP-RNAi vector (red). Many transfected cells are EdU ${ }^{+}$and appear as yellow (white arrows). They are abundantly present in the subventricular zone (right, above white dotted

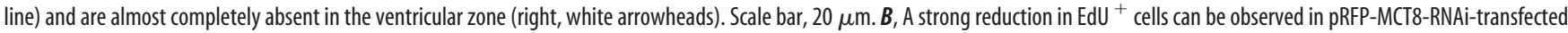
regions (white dotted arrows) resulting in a reduced number of yellow cells (white arrows). EdU ${ }^{+}$cells are also frequently present in the ventricular zone (right, white arrowheads). $\mathbf{C}$, PH $3^{+}$cells transfected with the pRFP-RNAi vector (white arrows) are abundantly present and located at the ventricular border (under white dotted line). Only few transfected cells do not express PH3 (white dotted arrows). Scale bar, $20 \mu \mathrm{m}$. D, Cells transfected with the pRFP-MCT8-RNAi vector expressing PH3 are more scarce (yellow cells, white arrows). $\boldsymbol{E}$, Scatter plots (including mean \pm SD) showing

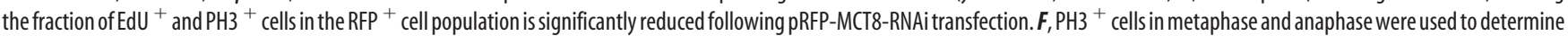
the orientation of the mitotic spindle. Theoretically, a vertical division $\left(90^{\circ}\right)$ produces two new progenitors, while a horizontal division $\left(0^{\circ}\right)$ produces a new progenitor cell and a neuroblast. A scatter plot (including mean \pm SD) shows the angle of the mitotic plane is on average $17^{\circ}$ smaller in the MCT8-knockdown condition. Each dot represents a mean angle of $\geq 10$ PH3 ${ }^{+}$cells per animal. Control, pRFP-RNAi transfection; MCT8-KD (knockdown condition), pRFP-MCT8-RNAi transfection; n, neuroblast; $p$, progenitor; sVZ, subventricular zone; VZ, ventricular zone. ${ }^{* *} p<0.01,{ }^{* * *} p<$ 0.001 . 
$60 \%$ of S-phase cells at E4 $\left(n=3\right.$, two-tailed $t$ test, $t_{(4)}=11.64$, $p=0.0003$; Fig. $3 E$ ) and $54 \%$ at E5 (data not shown, $n=5$, Mann-Whitney $U$ test, $p=0.0159$ ) following MCT8 knockdown. The fraction of M-phase cells in the RFP-positive population is also lower at E4 ( $n=9-11$, two-tailed $t$ test, $t_{(18)}=3.141$, $p=0.0056$; Fig. $3 E$ ), but the effect is not as strong as for the fraction of S-phase cells (a reduction of 21 vs $60 \%$, respectively). Finally, by measuring the angle of the mitotic spindle during the metaphase or anaphase in M-phase cells, we further investigated stem cell behavior. Per animal, one value comprises the mean angle of the mitotic spindle of $\geq 10$ cells on $\geq 2$ sections. The mean angle of the mitotic spindle is on average $17^{\circ}$ smaller in the pRFP-MCT8-RNAi-transfected PH3-positive cells, further indicating a premature switch to neuroblast-generating behavior at the expense of establishing a normal-sized progenitor cell pool $\left(n=9-11\right.$, two-tailed $t$ test, $t_{(18)}=4.045, p=0.0008$; Fig. $\left.3 F\right)$. The above data suggest that the cause of the reduced number of RFP-positive cells in the MCT8-deficient TeO at E12 can be traced back to cell proliferation defects in an early stage of corticogenesis.

\section{MCT8 knockdown causes impaired neurogenesis and migration of early-born and late-born cells.}

A remarkable observation at E12 is the incapacity of pRFPMCT8-RNAi-transfected cells to reach the outer layers of the TeO. In general, cells born before E5 (i.e., early-born, type-I neuroblasts) will form the inner and then the outer layers, while cells born after E5 (i.e., late-born, type-II neuroblasts) generate the middle layers (Nakamura and Sugiyama, 2004). We performed a birth-dating experiment to determine the migratory history (E8) and final tectal destination (E12) of early-born and late-born cells. Therefore, we labeled them with EdU respectively at E4 and E6, 1 or 3 d after electroporation at E3 (Fig. 4A). Untransfected EdU-labeled cells provided an additional internal control condition, as they are born simultaneously and can be used to compare their course of migration with that of transfected cells. We compared their location with EdU-labeled cells transfected with the pRFPRNAi or pRFP-MCT8-RNAi vector. In the ROI, we quantified the proportion of green cells $\left(\mathrm{EdU}^{+} \mathrm{RFP}^{-}\right)$and yellow cells $\left(\mathrm{EdU}^{+} \mathrm{RFP}^{+}\right)$ in each tectal layer relative to the total population of green or yellow cells in all layers, respectively. Hence, the values lie between 0 and 1 .

The TeO comprises three basic layers at E8. The ventricular zone at the bottom contains radial glial cells (RGCs) and lateborn neuroblasts starting their migration. The intermediary zone contains migrating neuroblasts and is less populated. Finally, the outer tectal plate consists of the first migrated cells that have reached their destination as well as migrating neuroblasts that will form the superficial middle and outer layers (Sugiyama and Nakamura, 2003). Most of the untransfected cells labeled with EdU at E4 reach the tectal plate at E8, as is also true for EdUpositive cells transfected with the pRFP-RNAi vector (Fig. $4 B$, left). However, pRFP-MCT8-RNAi-transfected cells labeled with EdU at E4 are significantly more abundant in the ventricular zone $\left(n=3\right.$, Sidak post hoc test following two-way ANOVA, $t_{(4)}=$ 6.9197, $p=0.00686$ ) and almost not present at all in the tectal plate $\left(t_{(4)}=4.879, p=0.0243\right)$ compared with the untransfected EdU-positive cells (Fig. $4 B-D$, left). The latter actually resemble the migratory pattern of all the EdU-positive cells in the control condition. This strongly suggests that MCT8-deficient type-I neuroblasts already fail to migrate normally in an early stage. The same trend was observed at E12 where the pRFP-MCT8-RNAitransfected EdU-positive cells are predominantly present in the inner layers $(n=3$, Sidak post hoc test following two-way
ANOVA, $\left.t_{(4)}=22.885, p<0.0001\right)$ and almost completely absent in the SGFS i $\left(t_{(4)}=12.064, p<0.0001\right)$, SGFS $g\left(t_{(4)}=\right.$ $4.273, p=0.0135)$, and SGFS a-f $\left(t_{(4)}=3.507, p=0.0394\right.$; Fig. $4 E$, left). Untransfected cells labeled with EdU at E6 can be found in all layers at E8, as is also true for all transfected EdU-positive cells at this stage (Fig. $4 B-D$, right). Hence, the radial migration of type-II neuroblasts seems to occur normally at first. However, at E12 many pRFP-MCT8-RNAi-transfected EdU-positive type-II neuroblasts are again blocked in the inner layers $(n=4$, Sidak post hoc test following two-way ANOVA, $t_{(4)}=11.997, p<$ $0.0001)$, and failed to migrate toward the SGFS i layer $\left(t_{(6)}=\right.$ $6.745, p=0.000103$ ) compared with untransfected EdU-positive cells (Fig. 4E, right). Together, the data indicate that both earlyborn and late-born MCT8-deficient neuroblasts fail to migrate toward their normal cortical destination and suggest the absence of a normal inside-out gradient.

In addition, the EdU birth-dating experiment enabled us to quantify to what extent cells in the transfected population contributed to neurogenesis in early phases based on a strategy similar to the one used by McGowan et al. (2012). We anticipated finding a higher relative contribution to the total population of EdU-positive cells in the group of cells transfected with the pRFPRNAi vector compared with the group of pRFP-MCT8-RNAitransfected cells, indicating that neurogenesis at an early phase was severely reduced. Therefore, we calculated the fraction of yellow cells $\left(\mathrm{EdU}^{+} \mathrm{RFP}^{+}\right)$in the total population of EdU-positive cells in the ROI at E12 for each condition. This fraction is indeed significantly smaller in the MCT8-knockdown condition compared with controls following EdU labeling at E4 $(n=3-5$, two-tailed $t$ test, $\left.t_{(6)}=6.95, p=0.0002\right)$ as well as EdU labeling at E6 $(n=4$, two-tailed $t$ test, $t_{(6)}=2.886, p=0.0139$; Fig. $\left.4 F, G\right)$. Hence, for both types of neuroblasts, the relative contribution to the total population of EdU-positive cells is decreased threefold due to MCT8 knockdown. This result is in line with our data (see MCT8 knockdown disrupts cell-cycle kinetics and obstructs progenitor cell pool expansion) and provides direct evidence that the origin of the reduced tectal cell number can be traced back to a diminished progenitor cell pool expansion in the pRFP-MCT8-RNAitransfected population, suggesting that the period of neurogenesis is shortened.

\section{Reduced reelin expression together with disorganized radial glial cell fibers could underlie impaired cell migration}

We further hypothesized that a reduced secretion of the protein reelin, encoded by the TH-responsive RELN gene and having a well known function in neuronal migration to establish the layers of the mammalian cortex, could be one of the reasons why postmitotic cells fail to migrate already at early stages. At E6, the TeO consists of the inner ventricular zone and the outer mantle zone, the latter containing the first differentiating neurons. Immunohistochemical staining of the reelin protein revealed clear expression in the mantle zone at E6. Detailed pictures of transfected cells confirm that reelin is secreted outside the cell body (Fig. 5A). Reelin is also present in the pRFP-MCT8-RNAi-transfected TeO, but reelin-positive cells are less abundant (Fig. 5B). Because we quantified reelin-secreting cells independently of whether cells were transfected or not, it was possible to include the untransfected side as an internal control. Therefore, we selected two $20 \times$ $20 \mu \mathrm{m}$ boxes in a strongly transfected region in the mantle zone of the transfected side (Fig. $5 A, B$, white boxes) and in a corresponding region in the mantle zone of the opposite, untransfected side, and did this for two sections per animal. In addition, we also measured the thickness of the reelin-positive layer and averaged 
A

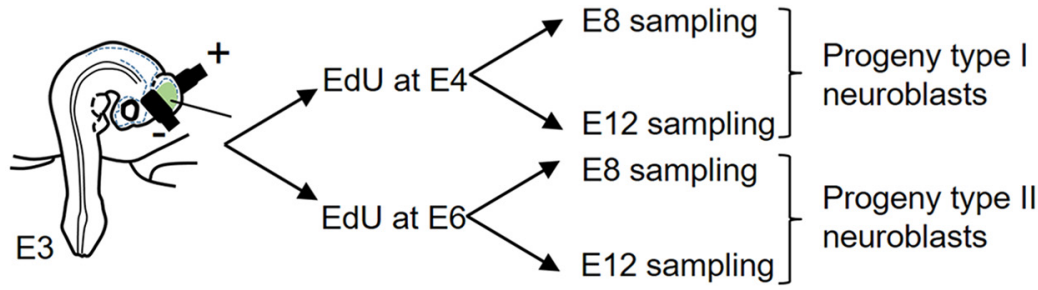

B

EdU at E4
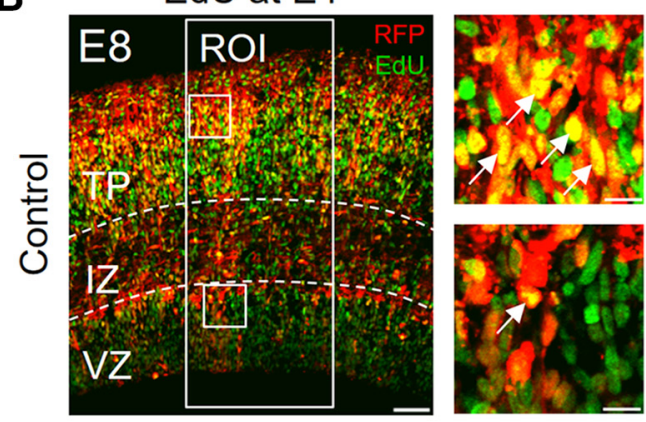

EdU at E6

C
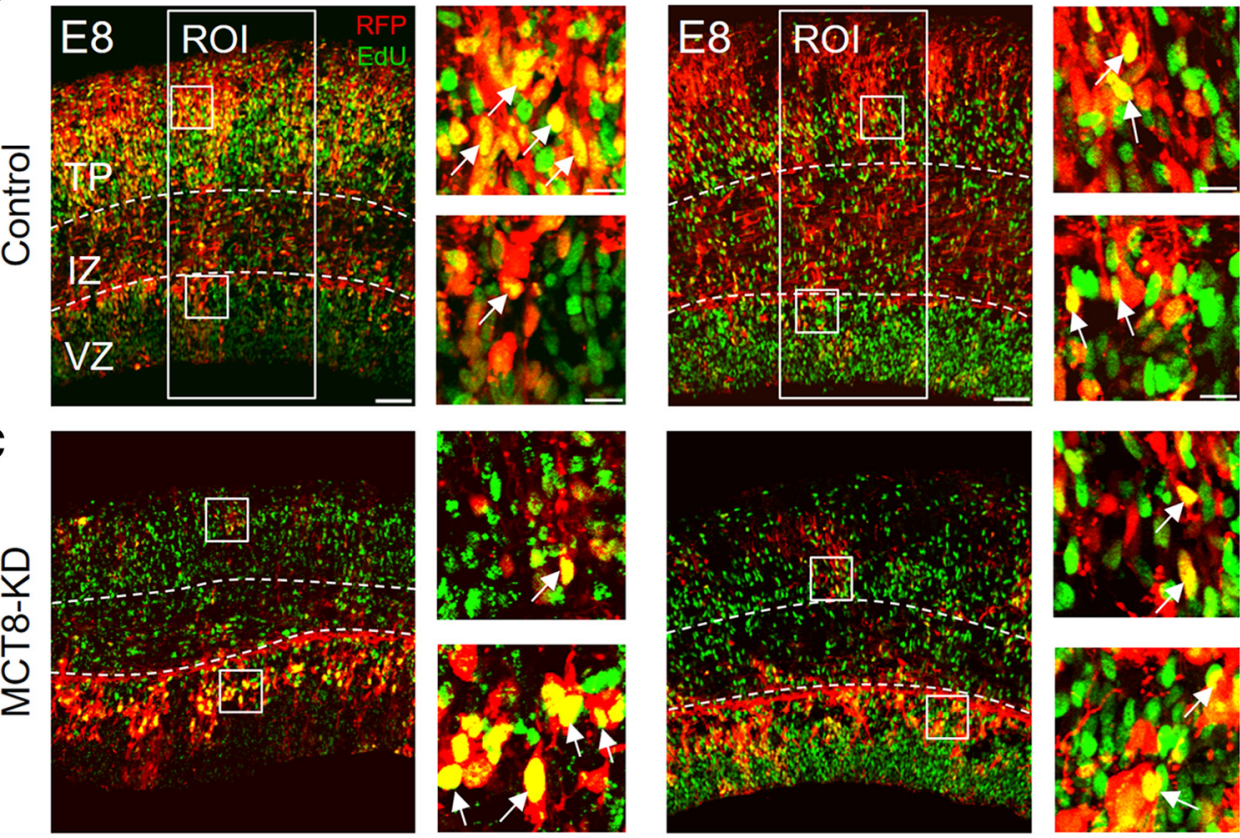

D

E8 (EdU at E4)

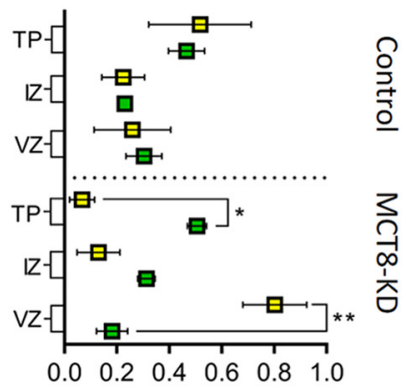

올
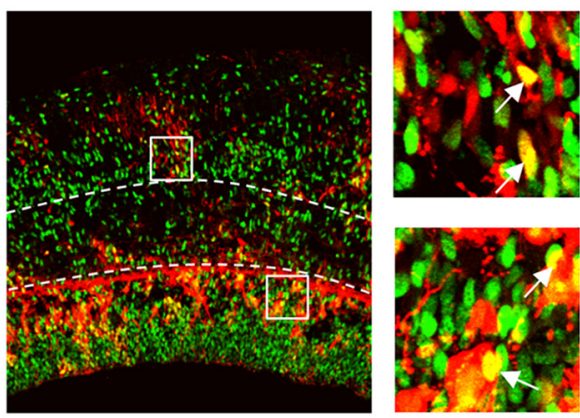

E8 (EdU at E6)

F
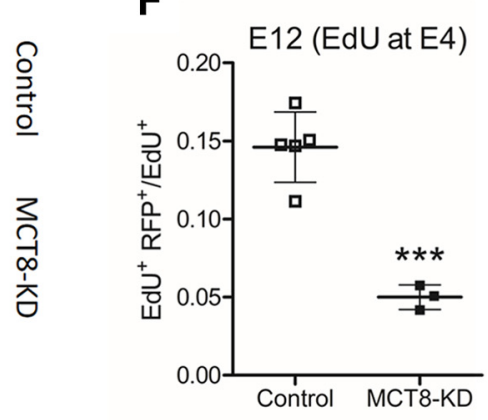

E

$\square \mathrm{EdU}^{+} \mathrm{RFP}^{+}$
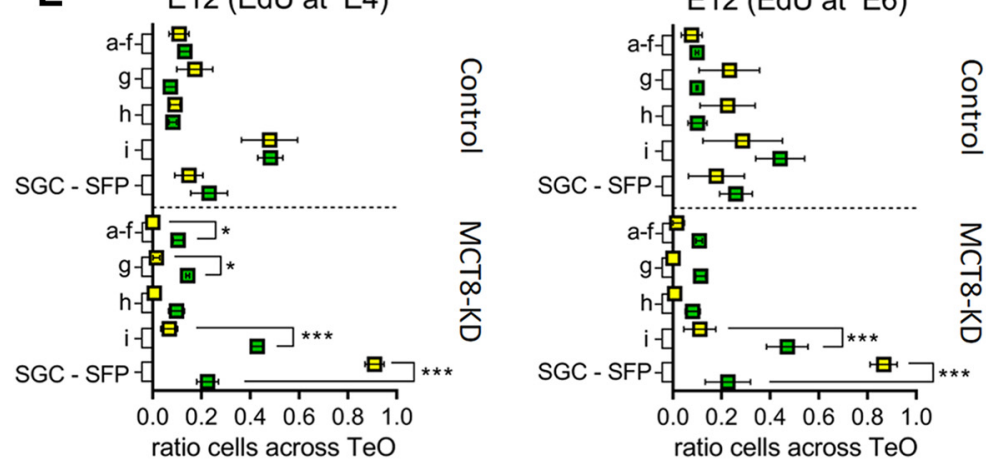

G

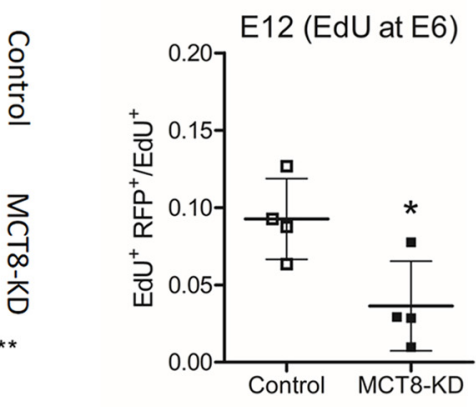

Figure 4. MCT8 knockdown causes impaired neurogenesis and migration of early-born and late-born cells. $A$, Experimental setup of the EdU birth-dating experiment. Following electroporation at E3, EdU was administered at E4 (predominantly labeling early-born, type-Ineuroblasts) or E6 (predominantly labeling late-born, type-II neuroblasts), and samples were taken at E8 (during migration) or E12 (migration finished). $\boldsymbol{B}, \mathrm{At}$ E8, EdU ${ }^{+}$early-born cells transfected with the pRFP-RNAi vector (yellow) are predominantly present in the outer tectal layer (left). Detailed images of the white boxes show many yellow cells (white arrows) in the tectal plate (TP; upper box) and only few in the ventricular zone (VZ; lower box). Late-born cells transfected with the pRFP-RNAivector are spread across all tectal layers (white arrows, right). Untransfected EdU ${ }^{+}$cells (green) follow a similar pattern of migration. Scale bars: large panels, $50 \mu \mathrm{m}$; detailed images, $10 \mu \mathrm{m}$. C, Early-born, pRFP-MCT8-RNAi- (Figure legend continues.) 
10 measurements in the transfected and untransfected side on each section. The reelin-positive layer is $17 \%$ thinner in the MCT8-knockdown condition compared with internal and external controls ( $n=7$, Sidak post hoc test following two-way ANOVA, $\left.t_{(12)}=5.95, p=0.00013\right)$. This observation is compatible with the significant $31 \%$ reduction in the number of reelinsecreting cells $(n=7$, Sidak post hoc test following two-way ANOVA, $t_{(12)}=7.18, p=0.00022$; Fig. $5 C$ ).

Proper alignment of RGC fibers is necessary to provide a scaffold for neuronal migration. Immunohistochemical staining of vimentin allows researchers to see these fibers in the TeO at E6 and was performed on five animals per condition, after which detailed pictures were taken of $\geq 2$ sections per animal to confirm our observations. The RGC fibers show a highly aligned organization in the control condition (Fig. 5D), while RGC fiber alignment is partially lost and appears to be less dense following MCT8 knockdown. Furthermore, a substantial number of RGC fibers fail to reach the outer $\mathrm{TeO}$ (Fig. $5 E$ ). Clusters of transfected cells are organized in radial columns in the control condition as they are closely associated with the RGC fibers. In contrast, pRFPMCT8-RNAi-transfected cells tend to be randomly clustered together and are not properly associated with these fibers, a presage of the E12 TeO phenotype supporting the hypothesis of early impaired migration.

\section{MCT8 knockdown causes a reduction in GABAergic and glutamatergic neurons}

As every cortical circuit depends on a correct balance of excitatory and inhibitory neurons, glutamatergic and GABAergic cell differentiation was assessed using the markers BRN3a and LHX1/5, respectively (Waite et al., 2011). BRN3a-expressing cells are abundantly present in the TeO at E12 and are spread across all layers, especially the inner layers and the SGFS g (Fig. 6A). The presence of large glutamatergic, pyramidal neurons in the inner layers stands out, confirming previous observations (Wylie et al., 2009), and these cells resemble those found in layer 5-6 in the mammalian cerebral cortex. Detailed pictures show many RFPpositive cells expressing this marker in various layers of the $\mathrm{TeO}$ (Fig. 6A, right). The density of BRN3a-expressing cells in the pRFP-MCT8-RNAi-transfected $\mathrm{TeO}$ is noticeably lower (Fig. $6 B)$, but a substantial percentage of RFP-positive cells still expresses BRN3a (Fig. 6B, right). We performed cell counts in an ROI of the mediolateral $\mathrm{E} 12 \mathrm{TeO}$ as we did for previous analyses. The total number of BRN3a-expressing cells is significantly re-

\footnotetext{
$\leftarrow$

(Figure legend continued.) transfected EdU ${ }^{+}$cells (yellow) are only present in the inner layers of $\mathrm{Te} 0$ (white arrows, left), while untransfected EdU ${ }^{+}$cells (green) are predominantly present in the outer tectal layer. In contrast, EdU ${ }^{+}$late-born pRFP-MCT8-RNAi-transfected cells (yellow) are observed in all tectal layers (white arrows, right) as are untransfected EdU ${ }^{+}$cells. D, Graphs (mean \pm SD) showing the distribution of untransfected EdU ${ }^{+}$cells (green squares) and transfected EdU ${ }^{+}$cells (yellow squares) across the tectal layers in the ROl at E8 were plotted as relative values, the sum of each population being 1. pRFP-MCT8-RNAi-transfected cells labeled with EdU at E4 clearly deviate from the normal migratory pattern (left graph, yellow squares), while cells labeled with EdU at E6 seem unaffected at E8 (right graph). Notice that EdU ${ }^{+}$cells transfected with the pRFP-RNAi vector as well as untransfected EdU ${ }^{+}$cells all follow the normal migratory pattern. $\boldsymbol{E}$, The same analysis in the ROI at E12 reveals blocked migration of earlyborn as well as late-born cells, as almost all pRFP-MCT8-RNAi-transfected EdU ${ }^{+}$cells are located in the inner layers. $\boldsymbol{F}, \mathbf{G}$, Neurogenesis in the population of early-born and late-born cells was calculated as the fraction of transfected EdU ${ }^{+}$cells relative to the total EdU ${ }^{+}$population. Scatter plots (including mean \pm SD) show neurogenesis in the early-born as well as the lateborn pRFP-MCT8-RNAi-transfected cell population is significantly reduced. Control, pRFP-RNAi transfection; MCT8-KD (knockdown condition), pRFP-MCT8-RNAi transfection; IZ, intermediate zone. ${ }^{*} p<0.05,{ }^{* *} p<0.01,{ }^{* * *} p<0.001$.
}

duced by $\sim 24 \%$ ( $n=8-9$, two-tailed $t$ test, $t_{(15)}=3.59, p=$ $0.0027)$, mainly due to a loss of BRN3a-expressing cells in the inner layers ( $n=8-9$, Sidak post hoc test following two-way ANOVA, $t_{(15)}=4.187, p=0.00038$; Fig. 6C). However, the fraction of transfected cells that have differentiated into BRN3a-expressing cells is similar in the control and MCT8knockdown condition $(n=8-9$, Mann-Whitney $U$ test, $p=$ 0.370; Fig. $6 D$ ), meaning that the loss of BRN3a-expressing cells is the sole consequence of the inadequate production of postmitotic neuroblasts (i.e., reduced neurogenesis). In addition, the number of BRN3a-expressing cells in the untransfected population is not affected ( $n=8-9$, two-tailed $t$ test, $t_{(15)}=0.494, p=0.6283$; Fig. $6 D$ ).

LHX1/5-expressing cells are also spread across the entire TeO at E12, but most of these cells now reside in the inner and middle layers in the control condition. Many inhibitory neurons are densely packed in the middle layers as was described previously (Wylie et al., 2009; Fig. 7A). Close examination of RFP-positive cells again indicates that some express LHX1/5 while others do not (Fig. 7A, right). A massive loss of LHX1/5-expressing cells can be observed in the MCT8-knockdown condition (Fig. 7B). Indeed, the number of LHX1/5-expressing cells in the ROI of the E12 TeO is significantly reduced ( $n=7-9$, Mann-Whitney $U$ test, $p=0.0003$ ), and more drastically than in the BRN3apositive cell population ( $34 \mathrm{vs} 24 \%$, respectively). In-depth analysis reveals a large reduction in LHX1/5-expressing cells in the inner layers $(n=7-9$, Sidak post hoc test following two-way ANOVA, $\left.t_{(14)}=2.815, p=0.0312\right)$, SGFS i $\left(t_{(14)}=6.089, p<\right.$ $0.0001)$, and the SGFS a-f $\left(t_{(14)}=3.41, p=0.00540\right.$; Fig. $\left.7 C\right)$, almost twofold more than for the BRN3a-expressing neurons. This is not only due to a smaller RFP-positive cell population; the fraction of LHX1/5-expressing cells in the RFP-positive population is also reduced by $13 \%\left(n=7-9\right.$, two-tailed $t$ test, $\mathrm{t}_{14}=$ $4.966, p=0.0002$ Fig. $7 D$ ), meaning that a substantial number of pRFP-MCT8-RNAi-transfected cells did not differentiate into this cell type. Intriguingly, the number of LHX1/5-expressing cells in the untransfected population is also decreased by $\sim 24 \%$ ( $n=7-9$, Mann-Whitney $U$ test, $p=0.0229$; Fig. 7D). Considering that there is no loss of cells in the untransfected population (Fig. 2D,E), this means that the reduced differentiation into GABAergic neurons could at least in part be the result of disrupted intercellular signaling.

\section{Discussion}

The aim of the present study was to examine which cellular processes necessary for establishing a layered cortex are affected by MCT8 deficiency at the level of the neural progenitors. Although previous studies using Mct 8 knock-out mice have provided crucial insights regarding the function of MCT8 in peripheral tissues, these mice do not replicate the neurological component of AHDS (Dumitrescu et al., 2006; Trajkovic et al., 2007), most likely due to the compensatory role of the organic anion transporting polypeptide 1C1 (OATP1C1; Mayerl et al., 2012). Accordingly, Mct8/ Oatp1c1 double-knock-out mice show a state of deep cerebral hypothyroidism and display compromised cerebral development and impaired locomotor behavior. However, as OATP1C1 is predominantly expressed at the blood-brain barrier, the question emerged to what extent the neurological abnormalities can be explained solely by the block of TH entry into the brain (Mayerl et al., 2014). Strong expression of Mct8 in the ventricular zone of the early cerebral cortex in rodents (Mohan et al., 2012; Mayerl et al., 2014), as well as the presence of ligand-occupied TH receptors during early neurogenesis in mouse (Flamant et al., 2002; 
A
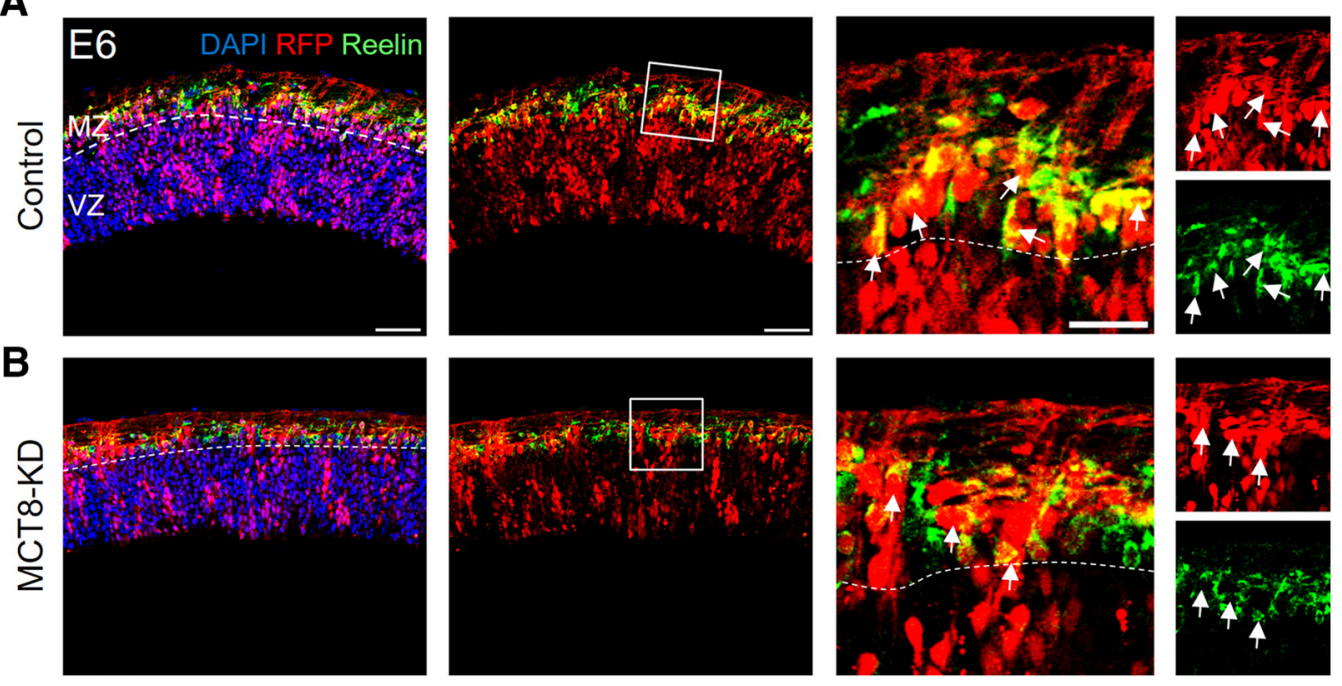

C
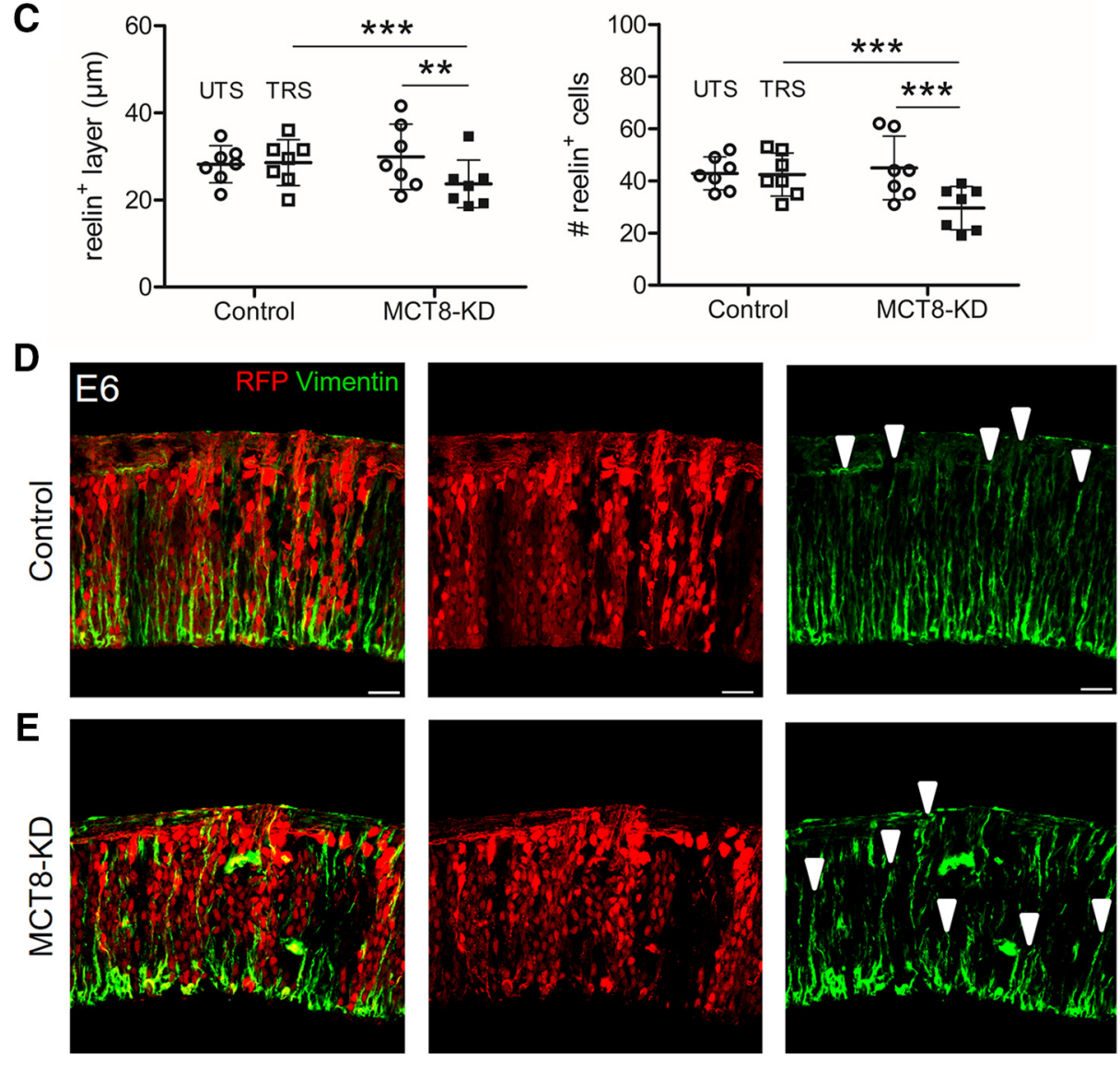

Figure 5. Reduced reelin expression together with disorganized radial glial cell fibers could underlie impaired cell migration. $A$, Reelin protein (green) is observed in the mantle zone of coronal sections through the Te 0 at E6. A detailed image of the white box shows many cells transfected with the pRFP-RNAi vector are reelin ${ }^{+}$(white arrows, right). Scale bars: left panels, $50 \mu$ m; detailed images, $20 \mu \mathrm{m}$. $\boldsymbol{B}$, The number of pRFP-MCT8-RNAi-transfected cells expressing reelin ${ }^{+}$is reduced (white arrows, right). $\boldsymbol{C}$, The thickness of the reelin ${ }^{+}$layer was measured in the mantle zone of the transfected side and in the mantle zone of the opposing untransfected side. Each value represents 10 measurements per animal. The number of reelin ${ }^{+}$cells was counted in two strongly transfected regions of the transfected side [white boxes $(20 \times 20 \mu \mathrm{m})$ in $\boldsymbol{A}$ and $\boldsymbol{B}$ ], and in two corresponding boxes of the opposing untransfected side. Scatter plots (including mean \pm SD) show the thickness of the reelin ${ }^{+}$layer as well as the number of reelin ${ }^{+}$cells is significantly reduced following pRFP-MCT8-RNAi transfection. $D$, Coronal section through the E6 Te0 shows that RGC fibers run parallel, reach the pial surface of the Te 0 (white arrowheads, right) and are associated with radial columns of RFP ${ }^{+}$cells in the control condition. Scale bar, $20 \mu \mathrm{m}$. $E$, MCT8 knockdown causes disorganization of RGC fibers, which do not always reach the pial surface (white arrowheads) and are less dense than normally expected. pRFP-MCT8-RNAi-transfected cells are more randomly clustered, and the columnar organization is partially lost. Control, pRFP-RNAi transfection;MCT8-KD (knockdown condition). pRFP-MCT8-RNAi transfection; MZ, mantle zone; VZ, ventricular zone. ${ }^{* *} p<0.01,{ }^{* * *} p<0.001$.

Quignodon et al., 2004) and human (Ferreiro et al., 1988), suggests an additional role for MCT8 facilitating $\mathrm{T}_{3}$ uptake at the level of neural progenitor cells themselves. We investigated this hypothesis using the chicken $\mathrm{TeO}$, which strongly expresses
MCT8 throughout the early stages of development (Geysens et al., 2012) and shares several structural and developmental features with the mammalian cerebral cortex (LaVail and Cowan, 1971; Nomura et al., 2009; Lever et al., 2014). 
A

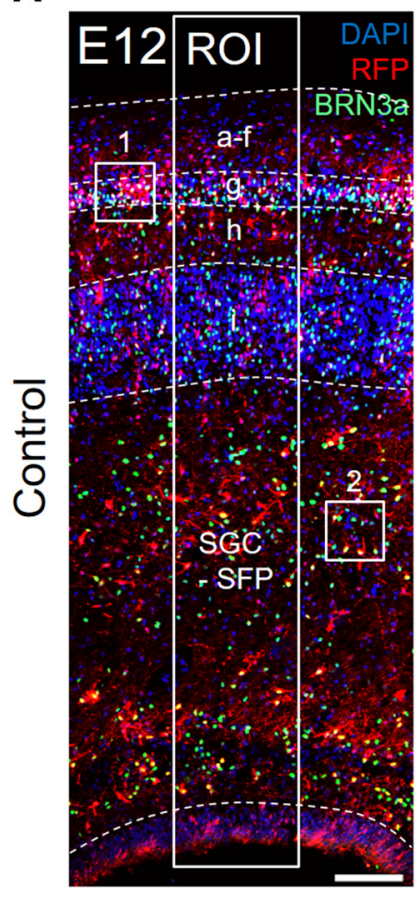

B

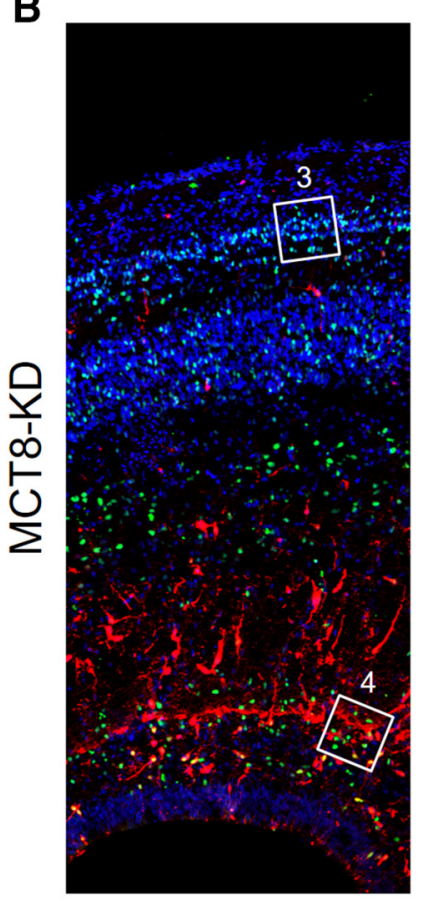

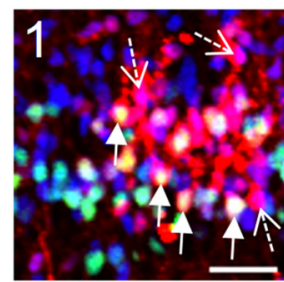
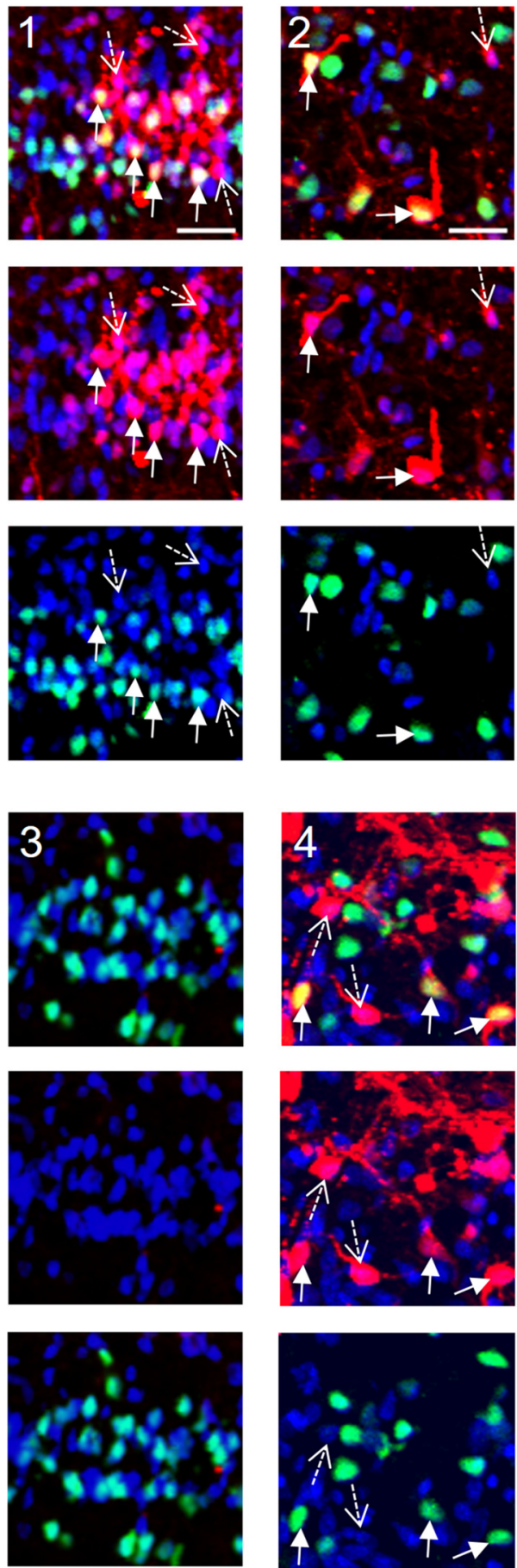

C
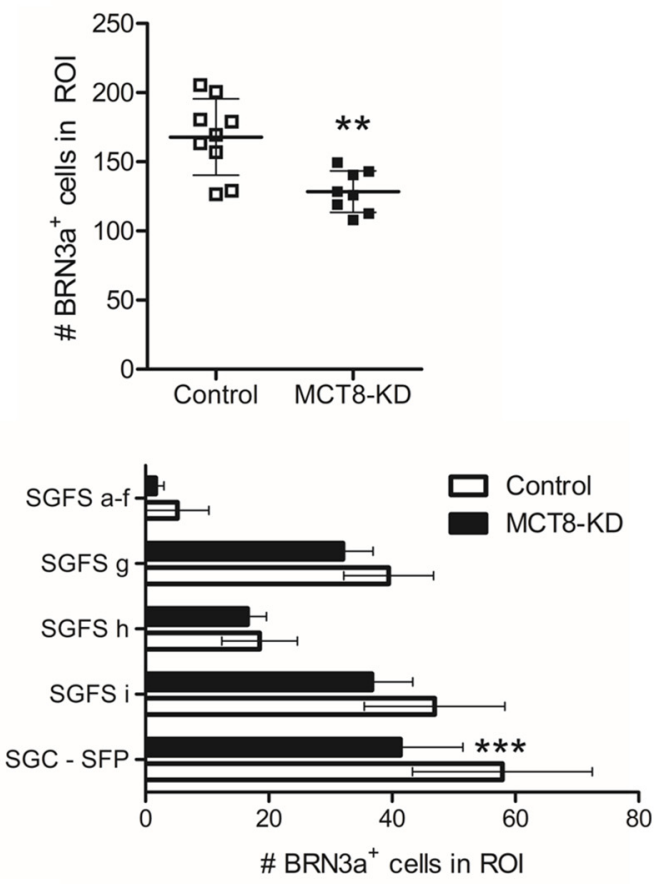

D
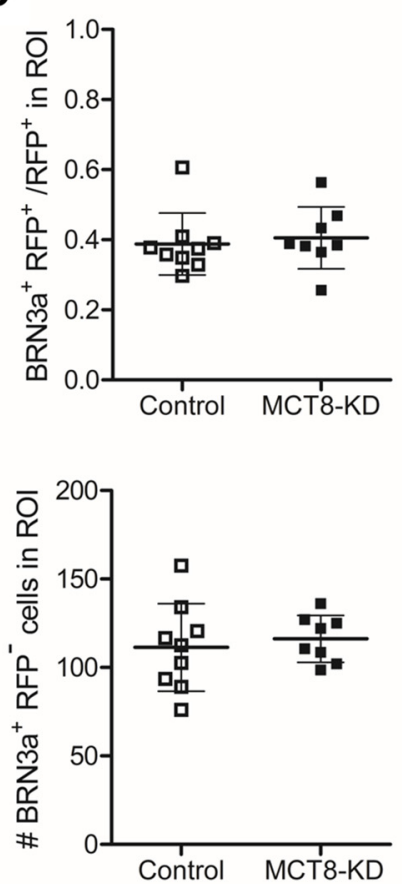

Figure 6. MCT8 knockdown causes a reduction in glutamatergic neurons at E12. A, Coronal section through the Te0 at E12 showing a clear presence of BRN3a ${ }^{+}$cells (green). Large pyramidal neurons can be observed in the stratum griseum centrale-stratum fibrosum periventriculare (SGC-SFP), while BRN3a ${ }^{+}$neurons are also densely packed in the SGFS $g$ and i. Cells were counted in a selected ROI. Magnifications of white boxes 1 and 2 show that a substantial number of cells transfected with the pRFP-RNAi vector also express BRN3a (yellow, white arrows), while others do not (white dotted arrows). Scale bars: left, $100 \mu \mathrm{m}$; detailed images, $10 \mu \mathrm{m}$. B, BRN3a ${ }^{+}$cells are less abundant following MCT8 knockdown. Magnifications show that pRFP-MCT8-RNAi-transfected cells did not reach the outer layers where no yellow cells are detected (magnification of white box 3 ). Meanwhile, a considerable number of yellow cells (white arrows) are still present in the inner layers, although they are not as dense as in the control condition (magnification of white box 4). Transfected cells that do not express BRN3a are also observed (white dotted arrows). C, Scatter plot (including mean \pm SD) showing the total number of $B R N 3 a^{+}$cells in the ROl is reduced following pRFP-MCT8-RNAi transfection. The bar graph (mean \pm SD) indicates this loss occurs in the inner layers. D, Scatter plots (including mean \pm SD) showing the fraction of BRN3a ${ }^{+}$cells in the RFP ${ }^{+}$population as well as the number of untransfected BRN3a ${ }^{+}$cells in the ROl is unaltered. Control, pRFP-RNAi transfection; MCT8-KD (knockdown condition), pRFP-MCT8-RNAi transfection. ${ }^{* *} p<0.01,{ }^{* * *} p<0.001$.

Our electroporation procedure proved efficient in targeting neural progenitor cells in vivo. We have confirmed MCT8 knockdown until the end point of the study, and demonstrated reduced intracellular TH signaling at an early stage. MCT8 deficiency re- sulted in reduced tectal thickness and cellular hypoplasia, and we gathered convincing evidence that cell-cycle defects and limited progenitor cell pool expansion are accountable for this phenotype. Likewise, the cerebrocortical neuroepithelium of prenatal 
A

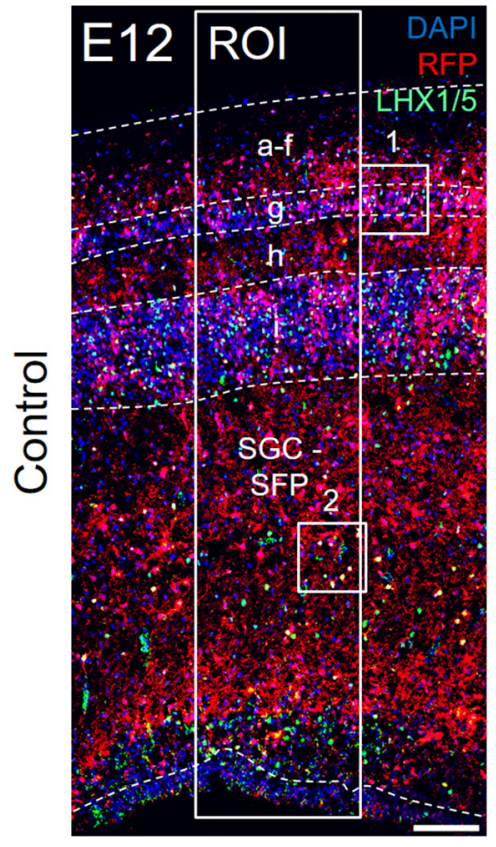

B

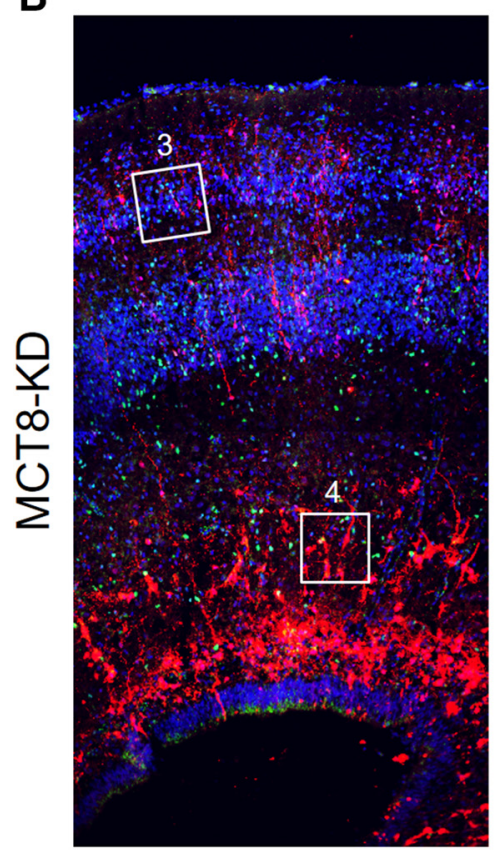

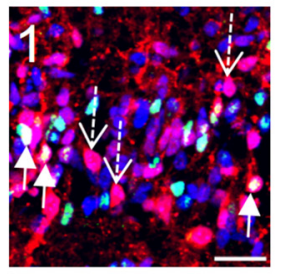
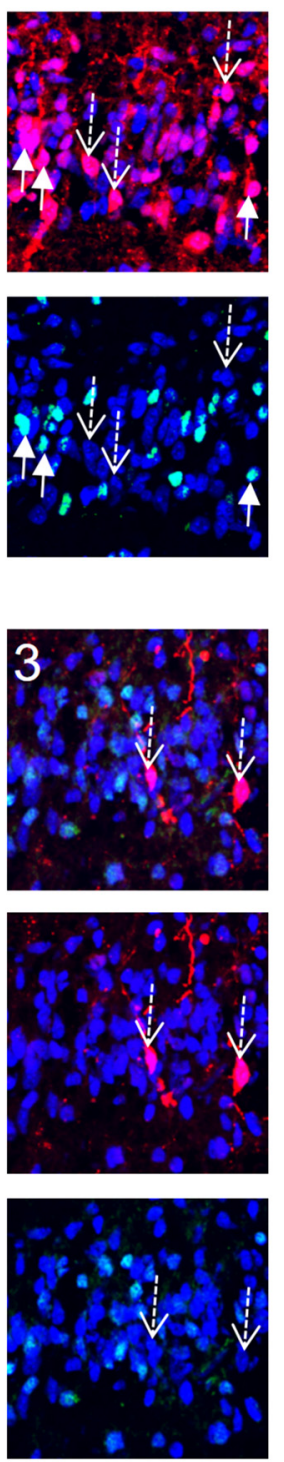
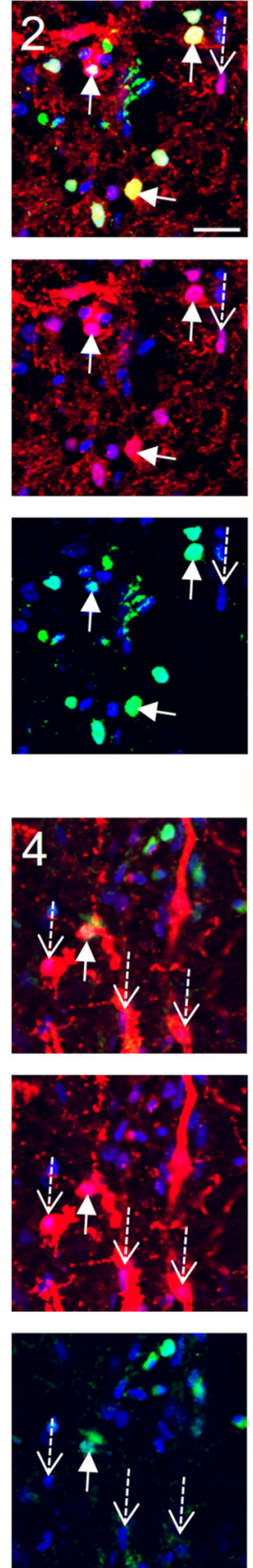

C
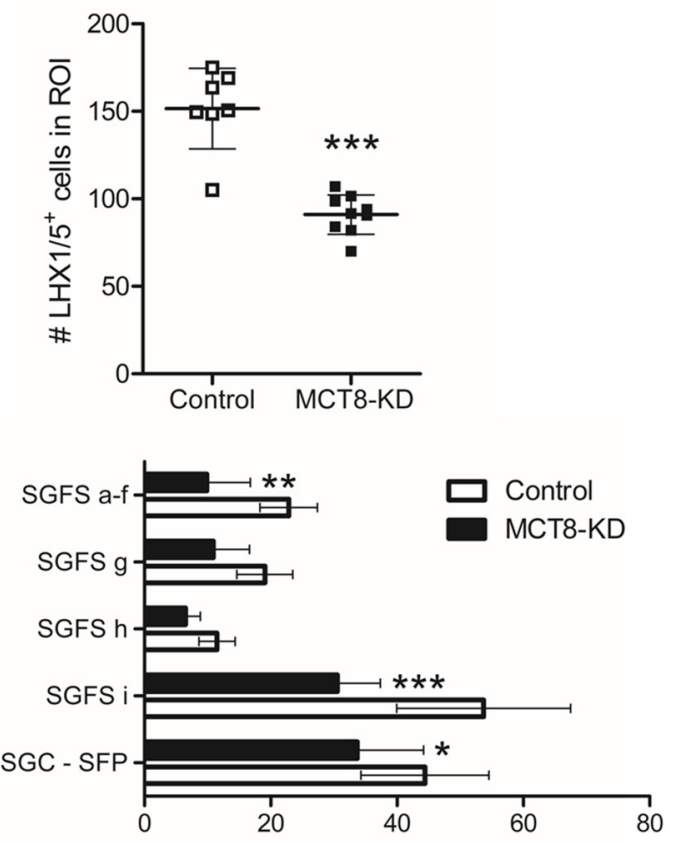

D
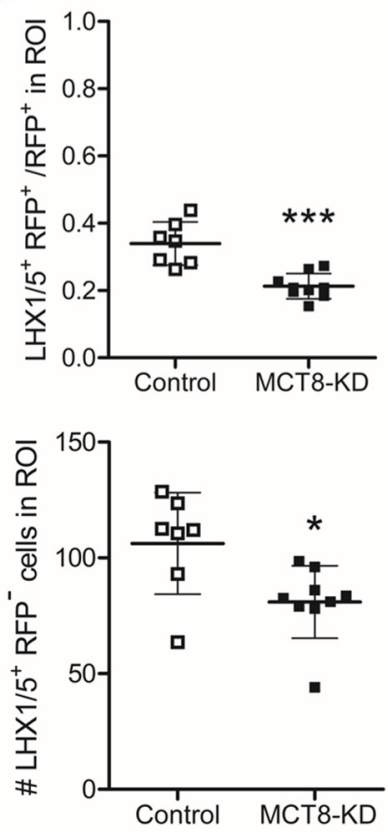

Figure 7. MCT8 knockdown causes a reduction in GABAergic neurons at E12. A, Coronal section through the Te 0 at E12 showing the presence of LHX1/5 ${ }^{+}$cells (green), which are especially dense in the SGFS i. Magnifications of white boxes 1 and 2 show a substantial number of cells transfected with the pRFP-RNAi vector express LHX1/5 (yellow, white arrows), while others do not (white dotted arrows). Scale bars: left, $100 \mu \mathrm{m}$; detailed images, $10 \mu \mathrm{m}$. B, The number of LHX1/5 ${ }^{+}$cells in the ROl is significantly reduced following MCT8 knockdown. Magnifications of white boxes 3 and 4 show only few pRFP-MCT8-RNAi-transfected cells express LHX1/5 (white arrowheads), while most of them do not (white dotted arrows). C, Scatter plot (including mean \pm SD) showing the total number of $\mathrm{LHX} 1 / 5^{+}$cells in the ROl is strongly reduced. The bar graph (mean $\pm \mathrm{SD}$ ) reveals this is the consequence of a major cell loss in various tectal layers. $D$, Scatter plot (including mean \pm SD) showing the fraction of $\mathrm{LHX} 1 / 5^{+}$cells in the pRFP-MCT8-RNAi-transfected population, as well as the number of $\mathrm{LHX} 1 / 5^{+}$cells in the untransfected population in the ROI, is strongly reduced. Control, pRFP-RNAi transfection; MCT8-KD (knockdown condition), pRFP-MCT8-RNAi transfection;SGC-SFP, stratum griseum centrale-stratum fibrosum periventriculare; SGFS, stratum griseum et fibrosum superficiale. ${ }^{*} p<0.05,{ }^{* *} p<0.01,{ }^{* * *} p<0.001$.

rats born from hypothyroid dams shows a reduced number as well as a scattering of S-phase cells (Pathak et al., 2011; Mohan et al., 2012). The latter observation indicates a shorter cell-cycle length as cells progress more rapidly toward the $M$ phase. A concomitant tendency to more asymmetrical divisions suggests that the MCT8-deficient progenitor cell pool prematurely shifts to neuroblast-generating behavior. While this initially favors neuroblast production, it probably quickly exhausts the progenitor cell pool, resulting in a hypoplastic cortex (Dehay and Kennedy, 2007). Similar effects could explain the reduced thickness of the outer cortical layers seen in Mct8/Oatp1c1 double-knock-out mice (Mayerl et al., 2014) and these observations are in line with 


\section{Cell Proliferation}

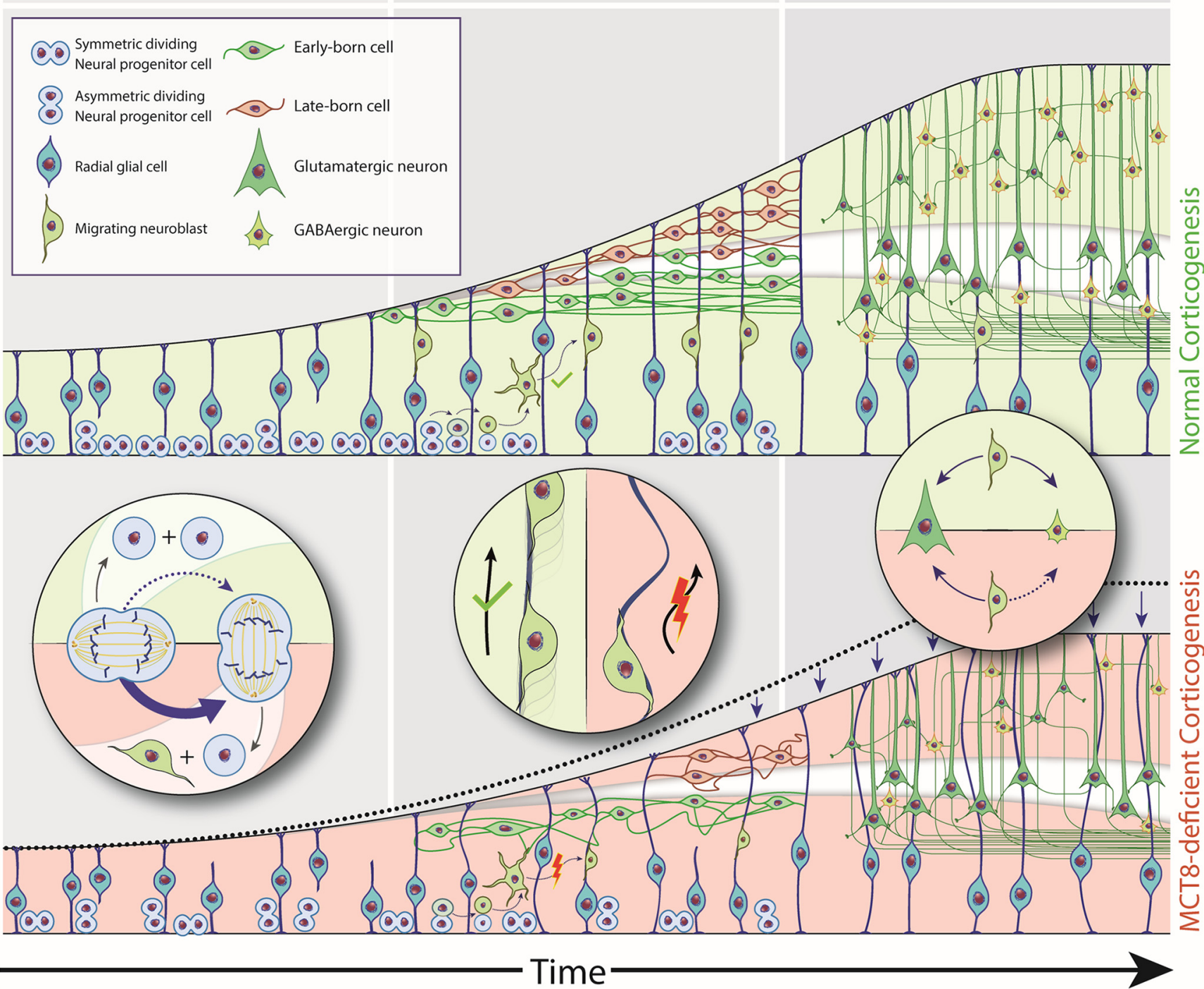

Figure 8. Schematic model summarizing how MCT8 deficiency in neural progenitors could disrupt cellular processes crucial for early corticogenesis.

the permanent neuronal loss in the early $\mathrm{TH}$-deficient rat cortex (Mohan et al., 2012). Conversely, $\mathrm{T}_{3}$ administration increased tectal cell proliferation and neurogenesis in Xenopus (Thompson and Cline, 2016). An increasing amount of evidence from epidemiological studies indeed confirms the necessity of TH action in promoting neurogenesis events in the first trimester of pregnancy (Berbel et al., 2010; Willoughby et al., 2014; Moog et al., 2017).

Our most distinctive observation was the failure of MCT8deficient cells to reach the outer TeO layers. The RELN gene encoding the glycoprotein reelin, known to be secreted by CajalRetzius neurons in the early mammalian cerebral cortex (Park and Curran, 2014), proves to be one of the affected genes. The current hypothesis is that the binding of reelin to postmitotic neuroblasts provokes an intracellular signaling cascade that allows them to properly migrate toward the pia. Endocytosis of this substrate-receptor complex reduces activity of the signaling cascade and subsequently stops cell migration (Chai and Frotscher, 2016). Reeler mice possessing a mutant Reln gene consequently display impaired migration of neuronal cells to the outer cortex, resulting in a loss of the layered pattern (D'Arcangelo et al., 1995). Reelin could have a similar action in radial cell migration in the chicken TeO (Nomura et al., 2009; Lever et al., 2014), and the reduced secretion of reelin by MCT8-deficient cells could disrupt this mechanism. In line with this, fetal rats from hypothyroid dams also display reduced reelin secretion by CajalRetzius cells and subsequent impaired cell migration (Pathak et al., 2011). A recent study suggests that reduced secretion of reelin might be the consequence of an indirect effect on the generation and/or differentiation of reelin-producing cells themselves (GilIbañez et al., 2017), and correspondingly suggests that reduced reelin secretion in the MCT8-deficient TeO could be due to the impaired neurogenesis.

Reelin signaling is also linked to correct alignment of RGC fibers (Noctor et al., 2001; Nomura et al., 2009), and MCT8 deficiency seems to disrupt the scaffold they form for neuronal migration. This would explain why our MCT8-deficient cells appear as a more chaotic collection of migrating neurons in contrast to the columnar organization in the control condition. The impaired radial migration from the ventricular zone toward the outer cortical regions 
resembles what has been seen in TH-deficient corticogenesis in rodents (Bernal et al., 2003). The sparse presence of reelin-secreting cells also coincides with disorganized RGC fiber alignment in the avian telencephalon where layers are absent (Nomura et al., 2008). Hence, the accumulation of MCT8-deficient cells in the inner layers of the $\mathrm{TeO}$ shows all the signs of the loss of the inside-out gradient.

Finally, we have shown that MCT8 deficiency affects neuronal differentiation. In contrast to mammals, where GABAergic cells originate from the ganglionic eminences and migrate tangentially to their final position in the cerebral cortex (Corbin and Butt, 2011), GABAergic cells in the chicken seem to predominantly originate from the ventricular zone. The generation of GABAergic neurons was drastically impaired in the MCT8-deficient $\mathrm{TeO}$, while the number of glutamatergic cells were probably only reduced due to earlier proliferation deficits. Previous studies already described the strong $\mathrm{TH}$ sensitivity of GABAergic neuronal differentiation in rat (Manzano et al., 2007) and human (Coghlan et al., 2012), and in chicken a substantial number of early MCT8deficient Purkinje cells did not express LHX1/5 (Delbaere et al., 2017). Mct8/Oatp1c1 double-knock-out mice also showed a profoundly compromised GABAergic neural network (Mayerl et al., 2014) and mct8-mutant zebrafish displayed circuit-specific deficiencies leading to altered behavior (Zada et al., 2014). MCT8 deficiency might therefore interfere with the generation of neuronal diversity in the cortex and cause an imbalanced cortical circuit. Hyperexcitability caused by reduced inhibitory synaptic input has been linked to increased susceptibility to seizures and is commonly associated with neuropsychiatric disorders (Kumar and Buckmaster, 2006; Chao et al., 2010). Epileptic seizures have been reported in AHDS patients, although not frequently (Schwartz et al., 2005; Novara et al., 2017), and loss of parvalbumin expression was observed in the cerebral cortex of an MCT8-deficient human fetus (López-Espíndola et al., 2014). Furthermore, neurological symptoms, including hyper-reflexia, contractures, and dyskinesia associated with AHDS (Schwartz et al., 2005) suggest disrupted signal processing in specific cortical circuits, often seen in congenital disorders (Rubenstein, 2011). These defects are also suggested to be a by-product of migratory defects (Ausó et al., 2004; Berbel et al., 2014). Intriguingly, differentiation into GABAergic neurons was also significantly reduced in the untransfected cell population of the TeO. These nonautonomous effects appear to echo findings from a study of the chicken cerebellum where MCT8-deficient Purkinje cells reduced proliferation of granule cells and obstructed their migration (Delbaere et al., 2017). This means that the effect of MCT8 deficiency in even one cell population could have widespread consequences for the development of the cortex as a whole.

We have shown that MCT8-dependent TH uptake by neural progenitor cells might be essential during the early stages of corticogenesis as MCT8 deficiency affects a variety of processes, including cell proliferation, migration, and differentiation, ultimately disrupting $\mathrm{TeO}$ development (Fig. 8). Although available data so far indicate that the primary cause of AHDS-related symptoms is failure of THs to cross the blood-brain barrier (Ceballos et al., 2009; Vatine et al., 2017), MCT8 seems to claim an additional, pivotal role in defining the availability of THs in neural progenitor cells themselves during early corticogenesis, independent of the immature blood-brain barrier. Furthermore, our observations support the notion that brain lesions in AHDS patients are most likely the result of locally reduced cellular TH signaling (Visser and Visser, 2012; López-Espíndola et al., 2014), and at least in part originate before birth, possibly in the first trimester of gestation (Berbel et al., 2009; Willoughby et al.,
2014). This forces us to reconsider the time window in which any therapeutical intervention in AHDS should be started (Groeneweg et al., 2017) and could have consequences for testing treatments now primarily focused on circumventing MCT8-dependent TH uptake at the brain barriers during postnatal stages (Kersseboom et al., 2014; Iwayama et al., 2016; Vatine et al., 2017). Moreover, it supports the concept of TH-dependent action from very early stages of corticogenesis (Préau et al., 2015; Andersen et al., 2017; Gil-Ibañez et al., 2017; Moog et al., 2017). In any case, future studies using both in vitro and in vivo models for MCT8 deficiency are needed to verify the possible crucial function of MCT8 in progenitor cells and determine the underlying mechanisms of its action.

\section{References}

Andersen SL, Carlé A, Karmisholt J, Pedersen IB, Andersen S (2017) Mechanisms in endocrinology: neurodevelopmental disorders in children born to mothers with thyroid dysfunction: evidence of fetal programming? Eur J Endocrinol 177:R27-R36. CrossRef Medline

Arjona FJ, de Vrieze E, Visser TJ, Flik G, Klaren PH (2011) Identification and functional characterization of zebrafish solute carrier Slc16a2 (Mct8) as a thyroid hormone membrane transporter. Endocrinology 152:50655073. CrossRef Medline

Ausó E, Lavado-Autric R, Cuevas E, Del Rey FE, Morreale De Escobar G, Berbel P (2004) A moderate and transient deficiency of maternal thyroid function at the beginning of fetal neocorticogenesis alters neuronal migration. Endocrinology 145:4037-4047. CrossRef Medline

Berbel P, Mestre JL, Santamaría A, Palazón I, Franco A, Graells M, GonzálezTorga A, de Escobar GM (2009) Delayed neurobehavioral development in children born to pregnant women with mild hypothyroxinemia during the first month of gestation: the importance of early iodine supplementation. Thyroid 19:511-519. CrossRef Medline

Berbel P, Navarro D, Ausó E, Varea E, RodríguezAE, Ballesta JJ, Salinas M, Flores E, Faura CC, de Escobar GM (2010) Role of late maternal thyroid hormones in cerebral cortex development: an experimental model for human prematurity. Cereb Cortex 20:1462-1475. CrossRef Medline

Berbel P, Navarro D, Román GC (2014) An evo-devo approach to thyroid hormones in cerebral and cerebellar cortical development: etiological implications for autism. Front Endocrinol (Lausanne) 5:146. CrossRef Medline

Bernal J (2017) Thyroid hormone regulated genes in cerebral cortex development. J Endocrinol 232:R83-R97. CrossRef Medline

Bernal J, Guadaño-FerrazA, Morte B (2003) Perspectives in the study of thyroid hormone action on brain development and function. Thyroid 13:1005-1012. CrossRef Medline

Bourgeois NM, Van Herck SL, Vancamp P, Delbaere J, Zevenbergen C, Kersseboom S, Darras VM, Visser TJ (2016) Characterization of chicken thyroid hormone transporters. Endocrinology 157:2560-2574. CrossRef Medline

Ceballos A, Belinchon MM, Sanchez-Mendoza E, Grijota-Martinez C, Dumitrescu AM, Refetoff S, Morte B, Bernal J (2009) Importance of monocarboxylate transporter 8 for the blood-brain barrier-dependent availability of 3,5,3'-triiodo-L-thyronine. Endocrinology 150:2491-2496. CrossRef Medline

Chai X, Frotscher M (2016) How does Reelin signaling regulate the neuronal cytoskeleton during migration? Neurogenesis 3:e1242455. CrossRef Medline

Chao HT, Chen H, Samaco RC, Xue M, Chahrour M, Yoo J, Neul JL, Gong S, Lu HC, Heintz N, Ekker M, Rubenstein JL, Noebels JL, Rosenmund C, Zoghbi HY (2010) Dysfunction in GABA signalling mediates autismlike stereotypies and Rett syndrome phenotypes. Nature 468:263-269. CrossRef Medline

Chatonnet F, Flamant F, Morte B (2015) A temporary compendium of thyroid hormone target genes in brain. Biochim Biophys Acta 1849:122-129. CrossRef Medline

Coghlan S, Horder J, Inkster B, Mendez MA, Murphy DG, Nutt DJ (2012) GABA system dysfunction in autism and related disorders: from synapse to symptoms. Neurosci Biobehav Rev 36:2044-2055. CrossRef Medline

Corbin JG, Butt SJ (2011) Developmental mechanisms for the generation of telencephalic interneurons. Dev Neurobiol 71:710-732. CrossRef Medline 
D’Arcangelo G, Miao GG, Chen SC, Soares HD, Morgan JI, Curran T (1995) A protein related to extracellular matrix proteins deleted in the mouse mutant reeler. Nature 374:719-723. CrossRef Medline

Das RM, Van Hateren NJ, Howell GR, Farrell ER, Bangs FK, Porteous VC, Manning EM, McGrew MJ, Ohyama K, Sacco MA, Halley PA, Sang HM, Storey KG, Placzek M, Tickle C, Nair VK, Wilson SA (2006) A robust system for RNA interference in the chicken using a modified microRNA operon. Dev Biol 294:554-563. CrossRef Medline

Dehay C, Kennedy H (2007) Cell-cycle control and cortical development. Nat Rev Neurosci 8:438-450. CrossRef Medline

Delbaere J, Vancamp P, Van Herck SL, Bourgeois NM, Green MJ, Wingate RJ, Darras VM (2017) MCT8 deficiency in Purkinje cells disrupts embryonic chicken cerebellar development. J Endocrinol 232:259-272. CrossRef Medline

Dumitrescu AM, Liao XH, Weiss RE, Millen K, Refetoff S (2006) Tissuespecific thyroid hormone deprivation and excess in monocarboxylate transporter (mct) 8-deficient mice. Endocrinology 147:4036-4043. CrossRef Medline

Dumitrescu AM, Fu J, Dempsey MA, Refetoff S (2013) MCT8-specific thyroid hormone cell-membrane transporter deficiency. In: GeneReviews (Pagon RA, Adam MP, Ardinger HH, Wallace SE, Amemiya A, Bean LJH, Bird TD, Fong CT, Mefford HC, Smith RJH, Stephens K, eds). Seattle, WA: University of Washington. Medline

Ferreiro B, Bernal J, Goodyer CG, Branchard CL (1988) Estimation of nuclear thyroid hormone receptor saturation in human fetal brain and lung during early gestation. J Clin Endocrinol Metab 67:853-856. CrossRef Medline

Flamant F, Poguet AL, Plateroti M, Chassande O, Gauthier K, Streichenberger N, Mansouri A, Samarut J (2002) Congenital hypothyroid Pax8(-/-) mutant mice can be rescued by inactivating the TR $\alpha$ gene. Mol Endocrinol 16: 24-32. CrossRef Medline

Friesema EC, Ganguly S, Abdalla A, Manning Fox JE, Halestrap AP, Visser TJ (2003) Identification of monocarboxylate transporter 8 as a specific thyroid hormone transporter. J Biol Chem 278:40128-40135. CrossRef Medline

Friesema EC, Grueters A, Biebermann H, Krude H, von Moers A, Reeser M, Barrett TG, Mancilla EE, Svensson J, Kester MH, Kuiper GG, Balkassmi S, Uitterlinden AG, Koehrle J, Rodien P, Halestrap AP, Visser TJ (2004) Association between mutations in a thyroid hormone transporter and severe X-linked psychomotor retardation. Lancet 364:1435-1437. CrossRef Medline

Geysens S, Ferran JL, Van Herck SL, Tylzanowski P, Puelles L, Darras VM (2012) Dynamic mRNA distribution pattern of thyroid hormone transporters and deiodinases during early embryonic chicken brain development. Neuroscience 221:69-85. CrossRef Medline

Gil-Ibañez P, García-GarcíaF, Dopazo J, Bernal J, Morte B (2017) Global transcriptome analysis of primary cerebrocortical cells: identification of genes regulated by triiodothyronine in specific cell types. Cereb Cortex 27:706-717. Medline

Groeneweg S, Peeters RP, Visser TJ, Visser WE (2017) Therapeutic applications of thyroid hormone analogues in resistance to thyroid hormone (RTH) syndromes. Mol Cell Endocrinol pii:S0303-7207(17)30116-8. CrossRef Medline

Gupta S, Sen J (2015) Retinoic acid signaling regulates development of the dorsal forebrain midline and the choroid plexus in the chick. Development 142:1293-1298. CrossRef Medline

Iwayama H, Liao XH, Braun L, Bárez-López S, Kaspar B, Weiss RE, Dumitrescu AM, Guadaño-FerrazA, Refetoff S (2016) Adeno associated virus 9-based gene therapy delivers a functional monocarboxylate transporter 8 , improving thyroid hormone availability to the brain of Mct8-deficient mice. Thyroid 26:1311-1319. CrossRef Medline

Kersseboom S, Horn S, Visser WE, Chen J, Friesema EC, Vaurs-BarrièreC, Peeters RP, Heuer H, Visser TJ (2014) In vitro and mouse studies supporting therapeutic utility of triiodothyroacetic acid in MCT8 deficiency. Mol Endocrinol 28:1961-1970. CrossRef Medline

Kumar SS, Buckmaster PS (2006) Hyperexcitability, interneurons, and loss of GABAergic synapses in entorhinal cortex in a model of temporal lobe epilepsy. J Neurosci 26:4613-4623. CrossRef Medline

Kurian MA, Jungbluth H (2014) Genetic disorders of thyroid metabolism and brain development. Dev Med Child Neurol 56:627-634. CrossRef Medline

LaVail JH, Cowan WM (1971) The development of the chick optic tectum.
I. Normal morphology and cytoarchitectonic development. Brain Res 28:391-419. CrossRef Medline

Lever M, Brand-Saberi B, Theiss C (2014) Neurogenesis, gliogenesis and the developing chicken optic tectum: an immunohistochemical and ultrastructural analysis. Brain Struct Funct 219:1009-1024. CrossRef Medline

López-Espíndola D, Morales-Bastos C, Grijota-Martínez C, Liao XH, Lev D, Sugo E, Verge CF, Refetoff S, Bernal J, Guadaño-Ferraz A (2014) Mutations of the thyroid hormone transporter MCT8 cause prenatal brain damage and persistent hypomyelination. J Clin Endocrinol Metab 99: E2799-E2804. CrossRef

Manzano J, Cuadrado M, Morte B, Bernal J (2007) Influence of thyroid hormone and thyroid hormone receptors in the generation of cerebellar $\gamma$-aminobutyric acid-ergic interneurons from precursor cells. Endocrinology 148:5746-5751. CrossRef Medline

Mayerl S, Visser TJ, Darras VM, Horn S, Heuer H (2012) Impact of Oatp1c1 deficiency on thyroid hormone metabolism and action in the mouse brain. Endocrinology 153:1528-1537. CrossRef Medline

Mayerl S, MüllerJ, Bauer R, Richert S, Kassmann CM, Darras VM, Buder K, Boelen A, Visser TJ, Heuer H (2014) Transporters MCT8 and OATP1C1 maintain murine brain thyroid hormone homeostasis. J Clin Invest 124: 1987-1999. CrossRef Medline

McGowan LD, Alaama RA, Freise AC, Huang JC, Charvet CJ, Striedter GF (2012) Expansion, folding, and abnormal lamination of the chick optic tectum after intraventricular injections of FGF2. Proc Natl Acad Sci U S A 109 [Suppl 1]:10640-10646. CrossRef Medline

Mendoza A, Hollenberg AN (2017) New insights into thyroid hormone action. Pharmacol Ther 173:135-145. CrossRef Medline

Mey J, Thanos S (2000) Development of the visual system of the chick. I. Cell differentiation and histogenesis. Brain Res Brain Res Rev 32:343-379. CrossRef Medline

Mohan V, Sinha RA, Pathak A, Rastogi L, Kumar P, Pal A, Godbole MM (2012) Maternal thyroid hormone deficiency affects the fetal neocorticogenesis by reducing the proliferating pool, rate of neurogenesis and indirect neurogenesis. Exp Neurol 237:477-488. CrossRef Medline

Molnár Z, MétinC, Stoykova A, Tarabykin V, Price DJ, Francis F, Meyer G, Dehay C, Kennedy H (2006) Comparative aspects of cerebral cortical development. Eur J Neurosci 23:921-934. CrossRef Medline

Moog NK, Entringer S, Heim C, Wadhwa PD, Kathmann N, Buss C (2017) Influence of maternal thyroid hormones during gestation on fetal brain development. Neuroscience 342:68-100. CrossRef Medline

Mughal BB, Leemans M, Lima de Souza EC, le Mevel S, Spirhanzlova P, Visser TJ, Fini JB, Demeneix BA (2017) Functional characterisation of Xenopus thyroid hormone transporters mct8 and oatp1c1. Endocrinology 158: 2694-2705. CrossRef Medline

Nakamura H, Sugiyama S (2004) Polarity and laminar formation of the optic tectum in relation to retinal projection. J Neurobiol 59:48-56. CrossRef Medline

Noctor SC, Flint AC, Weissman TA, Dammerman RS, Kriegstein AR (2001) Neurons derived from radial glial cells establish radial units in neocortex. Nature 409:714-720. CrossRef Medline

Nomura T, Takahashi M, Hara Y, Osumi N (2008) Patterns of neurogenesis and amplitude of Reelin expression are essential for making a mammaliantype cortex. PloS One 3:e1454. CrossRef Medline

Nomura T, Hattori M, Osumi N (2009) Reelin, radial fibers and cortical evolution: insights from comparative analysis of the mammalian and avian telencephalon. Dev Growth Differ 51:287-297. CrossRef Medline

Novara F, Groeneweg S, Freri E, Estienne M, Reho P, Matricardi S, Castellotti B, Visser WE, Zuffardi O, Visser TJ (2017) Clinical and molecular characteristics of SLC16A2 (MCT8) mutations in three families with the Allan-Herndon-Dudley syndrome. Hum Mutat 38:260-264. CrossRef Medline

Park TJ, Curran T (2014) Neurobiology: Reelin mediates form and function. Curr Biol 24:R1089-R1092. CrossRef Medline

Pathak A, Sinha RA, Mohan V, Mitra K, Godbole MM (2011) Maternal thyroid hormone before the onset of fetal thyroid function regulates reelin and downstream signaling cascade affecting neocortical neuronal migration. Cereb Cortex 21:11-21. CrossRef Medline

Préau L, Fini JB, Morvan-Dubois G, Demeneix B (2015) Thyroid hormone signaling during early neurogenesis and its significance as a vulnerable window for endocrine disruption. Biochim Biophys Acta 1849:112-121. CrossRef Medline

Quignodon L, Legrand C, Allioli N, Guadaño-FerrazA, Bernal J, Samarut J, 
Flamant F (2004) Thyroid hormone signaling is highly heterogeneous during pre- and postnatal brain development. J Mol Endocrinol 33:467476. CrossRef Medline

Roberts LM, Woodford K, Zhou M, Black DS, Haggerty JE, Tate EH, Grindstaff KK, Mengesha W, Raman C, Zerangue N (2008) Expression of the thyroid hormone transporters monocarboxylate transporter-8 (SLC16A2) and organic ion transporter-14 (SLCO1C1) at the blood-brain barrier. Endocrinology 149:6251-6261. CrossRef Medline

Rubenstein JL (2011) Annual research review: development of the cerebral cortex: implications for neurodevelopmental disorders. J Child Psychol Psychiatry. 52:339-355. CrossRef Medline

Schindelin J, Arganda-Carreras I, Frise E, Kaynig V, Longair M, Pietzsch T, Preibisch S, Rueden C, Saalfeld S, Schmid B, Tinevez JY, White DJ, Hartenstein V, Eliceiri K, Tomancak P, Cardona A (2012) Fiji: an opensource platform for biological-image analysis. Nat Methods 9:676-682. CrossRef Medline

Schwartz CE, May MM, Carpenter NJ, Rogers RC, Martin J, Bialer MG, Ward J, Sanabria J, Marsa S, Lewis JA, Echeverri R, Lubs HA, Voeller K, Simensen RJ, Stevenson RE (2005) Allan-Herndon-Dudley syndrome and the monocarboxylate transporter 8 (MCT8) gene. Am J Hum Genet 77:41-53. CrossRef Medline

Sugiyama S, Nakamura H (2003) The role of Grg4 in tectal laminar formation. Development 130:451-462. CrossRef Medline

Thompson CK, Cline HT (2016) Thyroid hormone acts locally to increase neurogenesis, neuronal differentiation, and dendritic arbor elaboration in the tadpole visual system. J Neurosci 36:10356-10375. CrossRef Medline
Trajkovic M, Visser TJ, Mittag J, Horn S, Lukas J, Darras VM, Raivich G, Bauer K, Heuer H (2007) Abnormal thyroid hormone metabolism in mice lacking the monocarboxylate transporter 8. J Clin Invest 117:627635. CrossRef Medline

Vatine GD, Al-Ahmad A, Barriga BK, Svendsen S, Salim A, Garcia L, Garcia VJ, Ho R, Yucer N, Qian T, Lim RG, Wu J, Thompson LM, Spivia WR, Chen Z, Van Eyk J, Palecek SP, Refetoff S, Shusta EV, Svendsen CN (2017) Modeling psychomotor retardation using iPSCs from MCT8deficient patients indicates a prominent role for the blood-brain barrier. Cell Stem Cell 20:831-843.e835. CrossRef Medline

Visser WE, Visser TJ (2012) Finding the way into the brain without MCT8. J Clin Endocrinol Metab 97:4362-4365. CrossRef Medline

Waite MR, Skidmore JM, Billi AC, Martin JF, Martin DM (2011) GABAergic and glutamatergic identities of developing midbrain Pitx2 neurons. Dev Dyn 240:333-346. CrossRef Medline

Willoughby KA, McAndrews MP, Rovet JF (2014) Accuracy of episodic autobiographical memory in children with early thyroid hormone deficiency using a staged event. Dev Cogn Neurosci 9:1-11. CrossRef Medline

Wylie DR, Gutierrez-Ibanez C, Pakan JM, Iwaniuk AN (2009) The optic tectum of birds: mapping our way to understanding visual processing. Can J Exp Psychol 63:328-338. CrossRef Medline

Zada D, Tovin A, Lerer-Goldshtein T, Vatine GD, Appelbaum L (2014) Altered behavioral performance and live imaging of circuit-specific neural deficiencies in a zebrafish model for psychomotor retardation. PLoS Genet 10:e1004615. CrossRef Medline 